\title{
Global Leadership for Sustainability
}

\author{
Louis W. Fry ${ }^{1, *}$ and Eleftheria Egel ${ }^{2, *(D)}$ \\ 1 Department of Management, Texas A\&M University-Central Texas, 1001 Leadership Place, \\ Killeen, TX 76549, USA \\ 2 Navigating Transformation, Female Entrepreneurship Consultancy, 79379 Muellheim, Germany \\ * Correspondence: lwfry@tamuct.edu (L.W.F.); NavigatingTransformation@amfortas.eu (E.E.)
}

check for updates

Citation: Fry, L.W.; Egel, E. Global Leadership for Sustainability.

Sustainability 2021, 13, 6360. https:// doi.org/10.3390/su13116360

Academic Editor: Francisco Guijarro

Received: 7 February 2021

Accepted: 19 May 2021

Published: 3 June 2021

Publisher's Note: MDPI stays neutral with regard to jurisdictional claims in published maps and institutional affiliations.

Copyright: (c) 2021 by the authors. Licensee MDPI, Basel, Switzerland. This article is an open access article distributed under the terms and conditions of the Creative Commons Attribution (CC BY) license (https:// creativecommons.org/licenses/by/ $4.0 /)$.

\begin{abstract}
Given the social and environmental challenges facing all organizations, there is a need for new leadership models, methods, and tools for implementing organizational change for sustainable development. Toward that end, we review current approaches to leadership for sustainability in terms of their conceptual frameworks and extant research, which all advocate a balanced stakeholder approach to leadership to address the social and environmental issues related to sustainability and sustainable development. Then, drawing from spiritual and being-centered leadership theories, we offer a model of Global Leadership for Sustainability (GLfS) that incorporates and extends the conceptual domain beyond current approaches to leadership for sustainability. In doing so we propose that spirituality, through the qualities of self-transcendence and interconnectedness, is critical for sustainability and is foundational for GLfS. We also emphasize the importance of cultivating a Global Mindset for Sustainability, which incorporates two ethical principles-an ethic of remote moral responsibility and an ethic of care and compassion. As a result, global leaders for sustainability become more committed to moving beyond satisfying stakeholders' demands for economic returns, toward a more sustainable, triple bottom line, balanced approach. Finally, we discuss implications for theory, research, and practice of GLfS.
\end{abstract}

Keywords: leadership for sustainability; sustainability; sustainable development; spiritual leadership; sustainability leadership; responsible leadership; conscious leadership; global mindset; ethics for sustainability

\section{Introduction}

By whatever name, something akin to spiritual renewal is the sine qua non of the transition to sustainability.

Orr [1]

We live in unprecedented times. Many organizations, some with revenues greater than the GDP of entire nations, are becoming increasingly international in terms of various businesses, activities, and interactions with customers, competitors, suppliers, employees, and other relevant stakeholders [2]. However, this global interconnectedness challenges organizations to create an encompassing strategy in a fragmented but connected environment that encompasses poverty and disease in Africa, the reliance on IT services in India, large-scale pollution in China, and increasingly critical consumers in home markets [3]. Multinational organizations are also expected to deal with the conflicting demands of a wide range of stakeholders from diverse multicultural, ethnic, linguistic, and religious backgrounds [4-8].

These demands are exponentially increasing as, according to a report by Ellen MacArthur Foundation in 2013 [9], by 2025 there will be 1.8 billion additional middle-class consumers, a $24 \%$ increase in global calorie consumption, a $47 \%$ increase in packaging, and a $41 \%$ increase in end-of-life materials. At the same time, we are currently using $50 \%$ more natural resources yearly than the Earth can replenish and $30 \%$ of the world's population ( $2.1 \mathrm{bln})$ 
lack clean water and basic hygiene. This trend has serious consequences as it is estimated that if we continue with "business as usual" we will require the resources of 2.9 planets to survive in 2050 [10,11].

To reverse this trend, organizations are now called to create new business models as well as new models of leadership for sustainability that can address the economic, social, and environmental pillars of sustainability, often referred to as the triple bottom line [12-14]. These models should allow for crossing multiple boundaries and balancing local responsiveness with global integration in order to effectively drive corporate performance, while addressing increasing demands for sustainable solutions from powerful socially- and environmentally-focused stakeholders [15-17].

In response, many leaders and their organizations are already engaged in significant efforts to address these challenging societal and environmental issues. However, recent research that has tracked the adoption of corporate sustainability strategies over time has found that, even though sustainable business models could generate 12 trillion US dollars of economic and market opportunities and increase employment by up to 380 million jobs by 2030 [13], businesses have been slow to tackle sustainability issues and are, on the whole, nowhere near having fully incorporated sustainability into their strategic thinking and operations [18,19].

A major proposition of this piece is that a new model of Global Leadership for Sustainability (GLfS) is necessary for the transformation and the continued success of organizations focusing on sustainability and sustainable development. Given that sustainability is deeply rooted in the sacredness of humans, sentient beings, and nature, we also propose that the development of spiritual capabilities is a particularly important aspect of GLfS, as these reflect an emerging consciousness by leaders who are choosing to live their lives and lead their organizations in ways that account for their impact on the earth, society, and the health of local and global economies [20]. This creates unique challenges since leaders and their organizations seeking to implement triple bottom line strategies would need to emphasize spiritual qualities, such as self-transcendence and interconnectedness, which are socially complex and causally abstruse, but nevertheless can be a source of competitive advantage as they are difficult to imitate [21,22].

With an overriding purpose of co-creating a conscious, flourishing world that works for everyone, GLfS is a leadership paradigm for organizational transformation to a learning organization designed to facilitate vision and value congruence across the individual, empowered team, organization, and stakeholder ecosystem levels (see Figure 1). GLfS requires cultivation of a global mindset for sustainability based on two ethical principles for sustainability, which foster hope/faith in a vision for sustainability and sustainable development and an organizational culture based on the values of altruistic love. Leadership for sustainability then satisfies fundamental needs of both leader and followers for spiritual well-being through a sense of (1) calling/purpose to be change agents for sustainability and (2) belonging or membership in a loving, supportive community for sustainable development. In turn, spiritual well-being positively influences the economic, social, and environmental outcomes for sustainability that are inherently represented through triple bottom line key performance indicators.

The purpose of this article is to offer a model of GLfS that incorporates and extends current approaches to leadership for sustainability. In doing so we first make the case that two qualities of spirituality, self-transcendence, and interconnectedness, are foundational for sustainability and sustainable development. Second, we review current approaches to leadership for sustainability in terms of their conceptual domain and extant research, which advocate a balanced stakeholder approach to leadership that explicitly addresses issues inherent in the triple bottom line as it relates to sustainability and sustainable development. Third, we propose that spiritual and being-centered leadership theories can be used as the foundation for a model of GLfS, as they encompass both spiritual qualities of self-transcendence and interconnectedness. In doing so, we build upon Egel and Fry's (2018) [23] work on global mindset, which makes the case that global leaders cultivate 
a global mindset only when they reach an elevated state of consciousness. At this level, leaders committed to sustainability, in addition to having a sense of self-transcendence and interconnectedness, incorporate two fundamental ethical principles into their strategic decision making; an ethic of remote moral responsibility and an ethic of care and compassion and will develop a Global Mindset for Sustainability (GMS). We then compare and contrast the conceptual domains of leadership for sustainability and demonstrate that the GLfS model incorporates and extends the conceptual domain of leadership for sustainability. Finally, we discuss implications for future theory, research, and practice of GLfS.

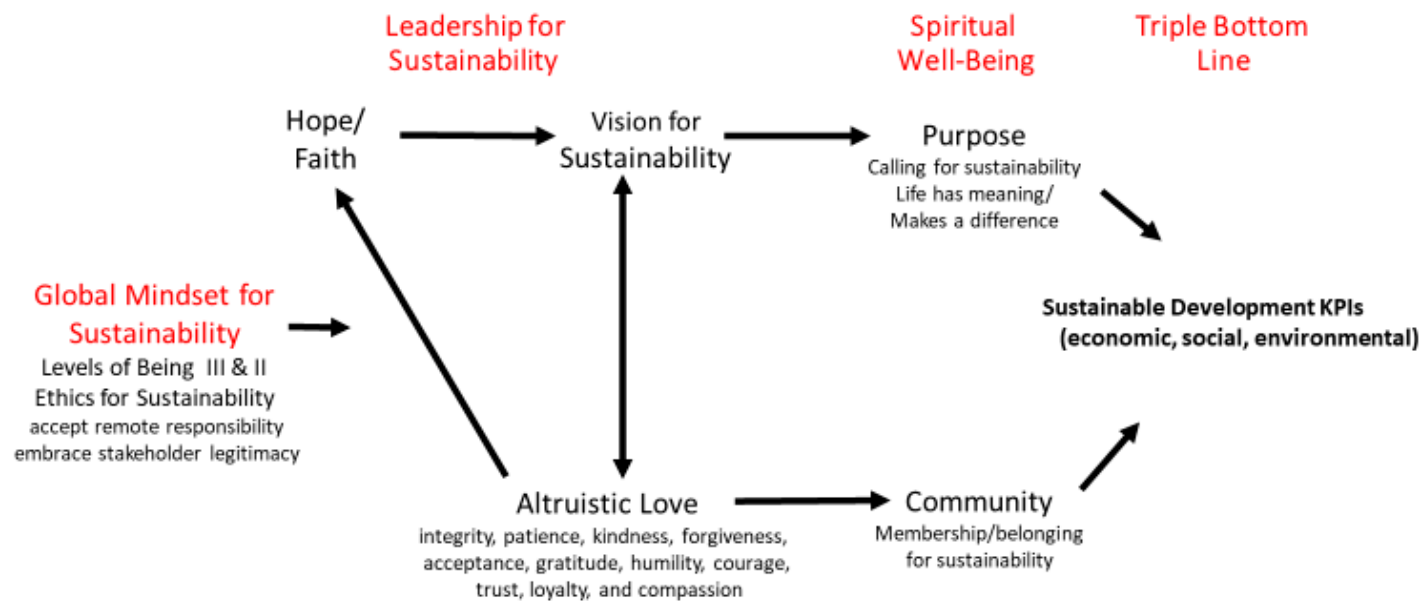

Figure 1. Model of Global Leadership for Sustainability.

This piece contributes to our understanding of global leadership for sustainability in several ways in that it:

- further explains the role leadership must play, and its importance for, a triple bottom line-based approach for sustainability and sustainable development;

- demonstrates that spirituality, through the qualities of self-transcendence and interconnectedness, is foundational for sustainability;

- reviews and integrates the relevant literature on leadership for sustainability;

- $\quad$ highlights the role spirituality must play in any model of leadership for sustainability;

- explores how a Global Mindset for Sustainability as a source for higher levels of consciousness, self-awareness, and other-centeredness serves as the source for GLfS;

- introduces two ethical principles for sustainability relating to social and environmental stakeholders that do not directly contribute to the firm's financial performance, but yet are necessary for sustainable development;

- explicates a causal model of GLfS that incorporates and extends current widely accepted approaches to leadership for sustainability;

- $\quad$ provides specific models, methods, and tools for the practice of GLfS.

\section{Spirituality and Sustainability}

While there are numerous definitions of spirituality, inherent to most of these is the quest for self-transcendence and the attendant feeling of interconnectedness with all things in the universe $[24,25]$. Self-transcendence is a state of consciousness whereby one seeks to go beyond self-interest toward an other-centered, broadened life perspective purpose or calling [21,26-29]. Interconnectedness is grounded in a sense of identity and community in which humans see themselves as equal to and interdependent with all other sentient beings and nature [30,31]. We are not separate from our communities and the larger world; we are intricately interconnected with one another in search of a common purpose.

These two qualities of spirituality, self-transcendence and interconnectedness, are also inherent to sustainability. Sustainability is most widely defined as a state of existence whereby social well-being and quality of life is maintained without degrading the ecological 
systems upon which present and future life depend [32]. In tandem, sustainability and sustainable development seek a balance among competing economic, environmental, and societal forces, with emphasis on the connections among economic and social equity, and environmental quality [20]. People and the Earth's resources are not just factors of production to be used and then discarded as waste when they become economically useless [22]. One term for this balanced emphasis that has seen wide acceptance is the triple bottom line [21].

Finding a balance among contradictory demands for economically, socially, and environmentally sustainable solutions is an undeniable leadership challenge that calls for a personal ethic that reaches beyond self-interest [20]. In its broadest sense, all approaches to sustainability assume the fundamental dignity of human beings, other sentient beings, and the environment requiring mutual respect, caring, and love [1,33]; that no human is entitled to diminish the well-being of another and that no generation has the right to take actions detrimental to the generations to come. Leopold [34] believed that giving an ethical stand to nature requires a more spiritual view of our relationships with one another as well as to nature. Pruzan and Pruzan-Mikkelsen [35], in interviews of spiritually motivated executives, found they were most inspired by spiritual qualities such as love, caring for others, purpose, compassion, divinity, and service.

David Orr [1] in "Four Challenges of Sustainability" argues that spiritual renewal is the sine qua non of the transition from the all-but-universal addiction to consumerism and the Neoliberal economic model based on perpetual growth. He further contends that such a spiritual renewal cannot take place without a heightened spiritual awareness based on compassion, courage, kindness, humility, gratitude, forgiveness, empathy, and humor, which, again, are the very same qualities that are foundational to the world's spiritual and religious traditions. This requires a shift to a higher level of consciousness that is more inwardly focused and spiritual, with an appreciation of the social and natural world that ultimately improves both the quality of life and the environment [36,37]. At this level of consciousness, leaders become committed to a sustainable world that insures not just continued survival, but the flourishing of future generations $[38,39]$.

\section{Leadership for Sustainability}

Leadership for sustainability is a relatively new field of scholarly inquiry that goes beyond more traditional leadership approaches that emphasize internal organizational processes and outcomes within limited or closed systems, although it is related to other leadership models that are relational and focus on systems change [40-43]. It includes a radically expanded approach to leadership that allows all who are committed to making a sustainable difference in their organizations, communities, and the broader society to be leaders [20]. Leadership for sustainability is thus enacted in organizations operating in open systems in an evolving and global ecosystem of stakeholders. This challenges the traditional neoliberal economic paradigm with its primary focus on maximizing shareholder wealth to the exclusion of those advocating social and environmental issues as championed through the seventeen United Nations "sustainable development goals" [44].

Leadership for sustainability thus goes beyond the trappings of formal position or legitimate power. Instead, these leaders find themselves in a wide array of collaborative relationships faced with the complex challenge of co-creating a common vision and building synergies among a diverse set of internal and environmental stakeholders that are often in conflict [20,45]. More recently, work in this area has evolved into three streams of scholarly inquiry, including sustainability leadership [46], responsible leadership [47], and conscious leadership [48,49]. All three focus on a balanced stakeholder approach to leadership that explicitly addresses issues inherent in the triple bottom line.

\subsection{Sustainability Leadership}

In a comprehensive bibliographic review, Hallinger and Suriyankietkaew [46] found the literature on sustainable (or sustainability) leadership to be modest in size but global 
in scope and growing rapidly, with the bulk of scholarship being published within the last decade. However, there is little consensus on the conceptualization of sustainability leadership, due to overlapping and different constructs and definitions. For example, Ferdig [20] defined sustainability leaders as taking conscious action to foster outcomes that nurture, support, and sustain healthy social, environmental, and economic systems. Avery and Bergsteiner (2011) [50] assert that sustainability leaders focus on long-term decision making for system-wide innovations to increase customer satisfaction through a highly engaged workforce, quality products, services, and solutions. Hargreaves and Fink [51] viewed sustainability leadership within the broad definition of sustainability as leadership that seeks to meet the needs of current society without compromising the ability of future generations to prosper. Suriyankietkaew and Avery [52] see sustainability leadership as leadership that creates long-term well-being and lasting value for all stakeholders, beyond just social and environmental responsibility, that produces increased profitable growth, resilience, and sustainability in organizations. Finally, Knight and Paterson's [53] review of behavioral competencies of sustainability leaders defined sustainability leadership as leaders who collaboratively work with stakeholders to integrate ethical, social, environmental, and consumer concerns into their core strategy and operations.

Nevertheless, there are common features that emerge from work grounded in the various conceptualizations of sustainability leadership [22,42,46,53-60]. Sustainability leaders are dedicated change agents for sustainability rooted in a learning organizational paradigm and spiritual way of being that is interconnected, inclusive, relational, and mindful and practiced in an open organizational and social stakeholder system within a particular institutional environment. Both sustainability leaders and their organization's culture adopt altruistic ethical values that are grounded in mutually beneficial stakeholder relationships and a shared purpose focused on sustainability and sustainable development. These values form the foundation for both leader-follower relationships and an organizational vision and strategies for sustainability that are co-created with stakeholders and jointly pursued. Sustainable leadership also emphasizes multiple outcomes for organizational effectiveness that go beyond traditional measures of success, such as employee productivity, commitment, and profit to include the "triple bottom line" of broader economic, social, and environmental outcomes; however, these outcomes are not the end goal. They encompass the degree to which organizations, communities, and societies embrace sustainability and sustainable development.

Reflecting the nascent state of the field, research to date on sustainability leadership has no clear focus as it is limited to six empirical studies that have been published in peer-reviewed journals (see Table 1). Two studies [52,61] used the theoretical framework and questionnaire derived from Avery and Bergsteiner's [41] honeybee model, a humanistic approach to sustainability that builds on the Rhineland sustainable leadership practices [62,63], which emphasize environmental sustainability, corporate social responsibility, and financial success. Consistent with the model, Suriyankietkew and Avery [61] found support for the hypothesis that sustainable leadership was significantly related to employee satisfaction for 20 of 23 of the sustainability practices explicated by the honeybee model. Similarly, Suriyankietkaew and Avery [52] found that 16 of the 23 practices we associated with financial performance, with amicable labor relations, valuing employees, a strong and shared vision, and social responsibility being the strongest predictors of long-term financial outcomes.

The other four studies utilized the 15-item measure developed by McCann and Holt [64] to explore sustainable leadership's influence on a range of variables. In terms of findings, these studies uncovered both mediating and moderating effects for sustainability leadership. Employee self-efficacy mediated the relationship between sustainable leadership and employee innovation [65]. Organizational learning partially mediated the relationship between sustainable leadership and sustainable performance [66]. Psychological safety mediated the relationship between sustainable leadership and sustainable performance, while psychological empowerment positively moderated the indirect relation- 
ship between sustainability leadership and sustainable performance through psychological safety [66]. Finally, Psychological safety mediated the relationship between sustainable leadership and sustainable performance and, additionally, psychological empowerment moderated the indirect relationship between sustainable leadership and sustainable performance through psychological safety such that this relationship is strong in the presence of high psychological empowerment [66].

\subsection{Responsible Leadership}

The call for responsible leadership has emerged as leaders have found themselves engaging stakeholders in an increasingly volatile, uncertain, complex, and ambiguous (VUCA) global environment. Similar to sustainability leadership, responsible leadership has seen growing interest in both academia and the business world with the initial seminal work emerging within the last fifteen years $[50,67,68]$. This literature also incorporates and extends more traditional leadership approaches (e.g., transactional/transformational, ethical, authentic, and servant leadership) that primarily emphasize relationships between leaders and followers within a closed organizational system.

As with sustainability leadership, there is little agreement on the conceptualization of responsible leadership due to overlapping and different constructs and definitions. To date, three distinct theoretical perspectives have gained relevance $[69,70]$. The stakeholder perspective conceptualizes responsible leadership across multiple levels of analysis as a purposeful, relational, inclusive, and ethical approach to dealing with a diverse population of stakeholders $[47,68,71-76]$. Agent views rest on the traditional assumption that the firm's primary responsibility lies in maximizing firm profits and shareholder value $[77,78]$. Converging perspectives attempt to balance economic, social, and environmental stakeholder demands through an emphasis on the triple bottom line [45,73,76,79-82].

However, there is an emerging consensus that responsible leadership exemplifies ethical behavior that inspires workers to "do well by doing good" for all stakeholders $[69,83]$. They also concentrate on using their influence and power to improve the well-being of all economic, social, and environmental stakeholders (e.g., the triple bottom line) rather than having a primary focus on enriching organizational elites and shareholders through profit maximization. In doing so, responsible leaders play a pivotal role in the stakeholder network and seek consensus to conflicting demands through authentic negotiation and dialog. These leaders must also embrace a number of roles: the leader as steward, citizen, visionary, servant, ethical role model, expert, coach, facilitator, and change agent $[47,84]$. Marques et al. [47] (p. 20) take all this into consideration to offer a more integrative definition of responsible leadership: "Responsible leaders become managers of relationships of different stakeholder groups inside and outside the firm, as well as managers in charge of developing sustainable business, via integrating micro and macro concerns."

Another arena for conceptual development of responsible leadership has emerged from the United Nation's focus on the Sustainable Development Goals [12,85]. From this perspective, responsible leadership implies the grounding of actions in a system of values which recognize stakeholder interdependence. It is a collective phenomenon occurring within a global context that creates an adaptive culture of responsibility that relies on farreaching planning, systemic analysis, and collaboration at all levels of society. Responsible leaders must have the moral depth, reflective awareness, multicultural sensitivity, critical thinking skills, and the wisdom to weigh competing stakeholder demands. They also must have a deep empathy and an innate understanding of one's colleagues, organizations, communities, the environment, and how all these factors relate to one other. Such leaders facilitate organizational transformations through a renewed sense of vision, purpose, values, and goals that are focused on sustainability and sustainable development.

In terms of research on responsible leadership (RL), although further advanced than the field of sustainability leadership due to the emergence of survey measures [84,86-89], there is still a paucity of empirical research on responsible leadership. To date thirteen 
empirical studies on responsible leadership have been published in peer-reviewed journals with no clear pattern of results yet to emerge (see Table 1).

In terms of direct relationships with responsible leadership, responsible leadership has been found to positively influence leader's perceived effectiveness, favorable stakeholder evaluations, employee engagement with the organization and society, work-life balance, unity with others, inspiration, expressing full potential, balancing tensions, corporate reputation, and financial performance, [83,84,87,90,91]. Leader empathy, positive affect, and universal value orientation positively predict responsible readership [84]. In addition, RL negatively influenced integrity with self-dimensions of an updated seven-dimension Comprehensive Meaningful Work Scale [87]. Liao and Zhang [92] discovered that three dimensions of responsible leadership (relationship building, relational governance, and sharing orientation) were positively related to incremental environmental innovation and that relational governance and sharing orientation had a positive effect on radical environmental innovation.

Table 1. Summary of Sustainability Leadership and Responsible Leadership Empirical Studies.

\begin{tabular}{|c|c|c|c|}
\hline Author(s) & Instrument Used & Sample & Results \\
\hline \multicolumn{4}{|l|}{ Sustainability Leadership } \\
\hline Iqbal and Ahmad [93] & McCann and Holt [64] & 369 SMEs from Pakistan & $\begin{array}{l}\text { Organizational learning partially mediated the } \\
\text { relationship between sustainable leadership and } \\
\text { sustainable performance }\end{array}$ \\
\hline Iqbal, Ahmad, Nasim, and Khan [66] & McCann and Holt [64] & $\begin{array}{l}405 \text { SMEs from Malaysia, } \\
\text { Indonesia, and Brunei } \\
\text { Darussalam }\end{array}$ & $\begin{array}{l}\text { Psychological safety mediated the relationship } \\
\text { between sustainable leadership and sustainable } \\
\text { performance } \\
\text { Psychological empowerment moderated the indirect } \\
\text { relationship between sustainable leadership and } \\
\text { sustainable performance through psychological safety } \\
\text { such that this relationship is strong in the presence of } \\
\text { high psychological empowerment }\end{array}$ \\
\hline Javed, Iqbal J., Iqbal S., and Imran [65] & McCann and Holt [64] & $\begin{array}{l}250 \text { software development } \\
\text { workers in Pakistan }\end{array}$ & $\begin{array}{l}\text { Employee self-efficacy mediated the relationship } \\
\text { between sustainable leadership and employee } \\
\text { innovation. }\end{array}$ \\
\hline Suriyankietkew and Avery [61] & Avery and Bergsteiner [50] & $\begin{array}{l}1152 \text { employees in small and } \\
\text { medium-sized enterprises } \\
\text { in Thailand }\end{array}$ & $\begin{array}{l}20 \text { of } 23 \text { SL practices positively related to employee } \\
\text { satisfaction with high staff engagement, valuing } \\
\text { employees, ethical behavior, considered organizational } \\
\text { change, a strong and shared vision, an enabling } \\
\text { culture, and quality in products and services being the } \\
\text { strongest predictors. }\end{array}$ \\
\hline Suriyankietkaew and Avery [52] & Avery and Bergsteiner [50] & $\begin{array}{l}439 \text { managers in small- to } \\
\text { medium-sized enterprises } \\
\text { in Thailand }\end{array}$ & $\begin{array}{l}20 \text { of } 23 \text { SL practices positively related to long term } \\
\text { financial performance with amicable labor relations, } \\
\text { valuing employees, a strong and shared vision, and } \\
\text { social responsibility being the strongest predictors. }\end{array}$ \\
\hline Qaisar, Noor, Adeel and Syed [66] & McCann and Holt [64] & $\begin{array}{l}405 \text { managers of Malaysian, } \\
\text { Indonesian, and Brunei SMEs }\end{array}$ & $\begin{array}{l}\text { Psychological safety mediated the relationship } \\
\text { between sustainable leadership and sustainable } \\
\text { performance. } \\
\text { Psychological empowerment positively moderated the } \\
\text { indirect relationship between SL and sustainable } \\
\text { performance through psychological safety. }\end{array}$ \\
\hline \multicolumn{4}{|l|}{ Responsible Leadership } \\
\hline $\begin{array}{l}\text { Afsar, Masqsoom, Shahjehan, Afridi, } \\
\text { Nawaz and Fazliani [94] }\end{array}$ & Voegtlin [89] & $\begin{array}{l}329 \text { employees and } \\
88 \text { supervisors in Pakistan }\end{array}$ & $\begin{array}{l}\text { Green shared vision mediated RL with } \\
\text { Proenvironmental behavior (PEB) } \\
\text { Moderating effect of RL was stronger for high locus of } \\
\text { control for both green shared vision and } \\
\text { organizational commitment on PEB }\end{array}$ \\
\hline Cheng, Feng, and Lin [95] & Voegtlin [89] & $\begin{array}{l}120 \text { sales team supervisors and } \\
426 \text { insurance salespeople } \\
\text { in China }\end{array}$ & $\begin{array}{l}\text { Low-level leader responsible behavior mediated the } \\
\text { relationship between high-level responsible leadership } \\
\text { and employee unethical pro-organizational } \\
\text { behavior (UPB) } \\
\text { Low-level leader-employee value congruence } \\
\text { moderated and the relationship between low-level } \\
\text { leader responsible leadership and UPB } \\
\text { High- and low-level leaders value congruence } \\
\text { moderated the relationship between high- and } \\
\text { low-level leader responsible leadership }\end{array}$ \\
\hline Doh, Stumph, and Tymon [86] & Doh et al. [86] & $\begin{array}{l}4352 \text { workers from } 28 \text { Indian } \\
\text { and global organizations }\end{array}$ & $\begin{array}{l}\text { Satisfaction mediated RL with intention to leave and } \\
\text { turnover }\end{array}$ \\
\hline
\end{tabular}


Table 1. Cont.

\begin{tabular}{|c|c|c|c|}
\hline Author(s) & Instrument Used & Sample & Results \\
\hline Han, Wang, and Yan [83] & Voegtlin [89] & 384 Chinese employees & $\begin{array}{l}\text { Autonomous and external motivation mediated the } \\
\text { relationship between RL and organizational } \\
\text { citizenship behavior for the environment }\end{array}$ \\
\hline Haque, Fernando, and Caputi [96] & Doh et al. [86] & 200 Australian Employees & Turnover intention mediated RL and org commitment \\
\hline He, Morrison, and Zhang [97] & Voegtlin [89] & $\begin{array}{l}261 \text { Millennial employees in } \\
\text { five-star hotels in China }\end{array}$ & $\begin{array}{l}\text { Green behavior played a mediation role between a } \\
\text { three-way interactive effect of CSR, GHRM, and } \\
\text { responsible leadership on employee performance after } \\
\text { controlling the effect of organizational identity. } \\
\text { Three-way interactive effects of CSR, GHRM, and } \\
\text { responsible leadership on employee green behavior } \\
\text { and performance }\end{array}$ \\
\hline Javed, Rashid, Hussain, and Yasir [91] & Voegtlin [89] & $\begin{array}{l}224 \text { senior level } \\
\text { Pakistani managers }\end{array}$ & $\begin{array}{l}\text { RL positively influenced corporate reputation and } \\
\text { financial performance } \\
\text { Responsible leadership negatively moderated the } \\
\text { relationship between CSR-reputation and CSR- } \\
\text { performance }\end{array}$ \\
\hline Liao and Zhang [92] & Voegtlin [89] & 208 manufacturing firms & $\begin{array}{l}\text { The three dimensions of responsible leadership } \\
\text { (relationship building, relational governance, and } \\
\text { sharing orientation) were positively related to } \\
\text { incremental environmental innovation. } \\
\text { Relational governance and sharing orientation were } \\
\text { positively related to radical environmental innovation. } \\
\text { Managerial discretion displayed a significant and } \\
\text { positive moderating effect on the relationships } \\
\text { between sharing orientation and incremental and } \\
\text { radical environmental innovation, and between } \\
\text { relational governance and radical environmental } \\
\text { innovation }\end{array}$ \\
\hline Lips-Wiersma, Haar, and Wright [87] & Lips-Wiersma et al. [87] & $\begin{array}{l}\text { International data set of } \\
879 \text { employees }\end{array}$ & $\begin{array}{l}\text { RL positively influenced unity with others, inspiration, } \\
\text { expressing full potential, and balancing tensions and } \\
\text { negatively influenced integrity with self-dimensions of } \\
\text { an updated seven-dimension Comprehensive } \\
\text { Meaningful Work Scale }\end{array}$ \\
\hline Mousa [88] & Mousa [88] & $\begin{array}{l}140 \text { physicians from an } \\
\text { Egyptian hospital }\end{array}$ & $\begin{array}{l}\text { Inclusive diversity climate mediated RL with } \\
\text { organizational commitment }\end{array}$ \\
\hline Mousa [90] & Mousa [88] & $\begin{array}{l}225 \text { female Egyptian } \\
\text { pharmacists }\end{array}$ & RL positively influenced work-life balance \\
\hline Mousa and Puhakka [98] & Mousa [88] & $\begin{array}{l}240 \text { physicians employed in } \\
\text { four Egyptian hospitals }\end{array}$ & $\begin{array}{l}\text { Organizational inclusion partially mediated the } \\
\text { relationship between RL and three dimensions of } \\
\text { organizational commitment }\end{array}$ \\
\hline $\begin{array}{l}\text { Voegtlin, Frisch, Walther, and } \\
\text { Schwab [84] }\end{array}$ & Voegtlin et al. [84] & $\begin{array}{l}\text { Three studies: } \\
\text { 1. } 195 \text { individual and } 95 \text { Swiss } \\
\text { employee-supervisor dyads. } \\
\text { 2. } 97 \text { Swiss college students. } \\
\text { 3.495 German workers }\end{array}$ & $\begin{array}{l}\text { Leader empathy, positive affect, and universal value } \\
\text { orientation were positively related to responsible } \\
\text { readership } \\
\text { RL positively related to the leader's perceived } \\
\text { effectiveness, favorable stakeholder evaluations and } \\
\text { employee engagement with the organization } \\
\text { and society }\end{array}$ \\
\hline
\end{tabular}

Eight studies discovered variables that mediated RL relationships, including green shared vision mediating RL with proenvironmental behavior, low-level leader responsible behavior mediating the relationship between high-level responsible leadership and employee unethical pro-organizational behavior, satisfaction mediating RL with intention to leave and turnover, autonomous and external motivation mediating RL and organizational citizenship behavior for the environment, turnover intention mediating RL and org commitment, and inclusive diversity climate mediating RL with organizational commitment $[83,86,88,94-96]$. Mousa and Phuhakka [98] found that organizational inclusion partially mediated the relationship between RL and three dimensions of organizational commitment. Finally, He, Morrison, and Zhang's [97] study revealed that green behavior played a mediation role between a three-way interactive effect of CSR, GHRM, and responsible leadership on employee performance after controlling the effect of organizational identity.

Five studies uncovered variables that moderated responsible leadership relationships with other variables. Afsar et al. [94] found that the moderating effect of RL was stronger for high locus of control for both green shared vision and organizational commitment on proenvironmental behavior. Cheng et al. [95] explored the relationship between leader 
and employee value congruence and levels of RL. They discovered that (1) high- and low-level leaders value congruence moderated the relationship between high- and lowlevel leader responsible leadership and (2) Low-level leader-employee value congruence moderated and the relationship between low-level leader responsible leadership and unethical pro-organizational behavior. Javed et al. [91] conducted a study which revealed that RL negatively moderated the relationship between CSR-reputation and CSR- performance. Then:

Liao and Zhang [92] revealed that managerial discretion plays a significant and positive moderating role in the relationships between sharing orientation and incremental and radical environmental innovation, and between relational governance and radical environmental innovation. Finally, He, Morrison, and Zhang [97] unearthed a three-way interactive effect of CSR, GHRM, and responsible leadership on employee green behavior and performance that was significant and positive.

\subsection{Conscious Leadership}

Conscious leadership is primarily addressed in the practitioner and popular literature as a central component of Conscious Capitalism $[99,100]$, which is a widely acknowledged and accepted approach for organizations committed to sustainability and the triple bottom line [49,101-103]. However, to date there has been minimal scholarly enquiry and no empirical research published in peer reviewed journals. We included it here as a nascent emerging paradigm due to its future potential for scholarly research on leadership for sustainability that would have a natural link to practical application.

Conscious Capitalism is a way of thinking about capitalism and business that better reflects the challenges inherent in our human journey, the state of our world today, and the potential for business to make a positive impact in the world (Conscious Capitalist Credo, n.d.) [104]. Organizations and leaders committed to Conscious Capitalism focus on the triple bottom line in the belief that it is possible to have superior corporate performance while also delivering value for all other stakeholders simultaneously. Four foundational tenets, higher purpose, stakeholder orientation, conscious culture, and conscious leadership, provide the basis for the Conscious Capitalism organizational paradigm, with conscious leadership being viewed as the most important tenet for Conscious Capitalism and creating conscious businesses [48,49,102,103].

Conscious leaders inspire positive transformation and keep the business focused on its higher purpose by mentoring, motivating, developing, and inspiring the people within the organization to create value for all of the organization's stakeholders. They also act as an energizing and unifying force to create and reinforce conscious cultures through values based on trust, authenticity, caring, transparency, integrity, learning, and empowerment. Moreover, conscious leaders have a world-centric view that encompasses all sentient beings and the planet, care passionately for, and are wholly committed to the company's purpose instead of personal self-interest. As change agents, they believe that doing well by doing good and aligning the needs of all stakeholders will lead to performance excellence $[100,105]$. They lead with love-treating business as an opportunity to serve and uplift humanity and communities, rather than as an engine to enrich investors and managerial elites. They place their highest priority on purpose through a vision for the value they can contribute to a sustainable world. Moreover, conscious leaders are emotionally and spiritually mature, have heightened self-awareness, and other-centered ethical values that go beyond doing just what is legal [106]. Rather than following a carrot and stick approach, conscious leaders create inclusive, empowered teams that have a strong sense of meaning in their work and can make decisions without fear of failure [103,107].

Conscious leaders also exhibit high levels of analytical, emotional, spiritual, and systems intelligence. Since their personal calling is aligned with the organization's purpose, they find joy in their work, helping others grow and evolve to help shape a better, sustainable future through an inclusive and holistic mindset and other-centered values such as goodness, justice, truth, love, kindness, and the alleviation of suffering $[48,49,106]$. Perhaps 
most importantly, conscious leaders embrace self-awareness through contemplative practices (e.g., prayer, meditation, Tai Chi, yoga, chanting, visualizations, and affirmations), which allows them to be more present. This helps ensure that they are able to better discern their strengths and weaknesses and thus not be overly influenced by negative emotions so as to not fall blindly or unconsciously into selfish actions that are inappropriate, destructive, or self-contradictory [49].

\section{Global Leadership for Sustainability}

The GLfS model (see Figure 1) is grounded in both being-centered leadership theory [25], Spiritual leadership theory, and the spiritual leadership model, which has seen extensive research, validation, and application [21,108-111]. We now explore the components of the GLfS model to support our major proposition that GLfS is necessary for the transformation and the continued success of organizations focusing on sustainability, sustainable development, and maximizing the triple bottom line.

\subsection{Global Mindset for Sustainability}

The field of global leadership emerged in the 1990s in response to a recognition that most executives working in global firms were not able to adequately deal with the complexities of globalization; namely, unpredictable markets, turbulent economic conditions, and uncertainties surrounding technological development [112]. The field distinguishes itself from mainstream leadership research in its emphasis on the contextual or environmental aspect of leadership [113]. The initial focus of scholarly research in this area was on the capabilities of effective global leaders [15,112-115].

However, the new and significant issues global organizations face, such as climate change and acute economic and social inequalities, put additional demands on organizations to incorporate the needs of diverse stakeholders through a balanced focus on economic profits, social impact (including employees), and environmental sustainability [21,116-118]. This reflects an emerging consensus for global leaders for sustainability to account for their organization's impact on the earth, society, and the health of local and global economies. However, even though the importance of personal ethical values such as honesty and integrity have been stressed by some authors, the literature on global leadership has not emphasized issues surrounding sustainability and the triple bottom line $[119,120]$.

Pless, Maak, and Stahl [73] were the first who attempted to close this gap by integrating the fields of global leadership and responsible leadership. They extended the scope of global leadership by integrating the responsible leadership principle of accountability towards stakeholders in a global business context. Maak, Borecka, and Pless [2] stated that development of global leaders requires a transformational process. To that end they proposed international volunteerism programs as experiences that challenge the global leader psychologically and promote social consciousness and community engagement at a global level. However, we contend that this approach may make global leaders aware of ethical issues involving societal and environmental sustainability but does not necessarily lead to other-centeredness through self-transcendence and interconnection. Other-centeredness, which results in global leaders being positive change agents for sustainability, requires a higher level of consciousness. Here we argue that our approach to cultivating a global mindset for sustainability offers a roadmap that makes this transition feasible and maintainable.

\subsubsection{Cultivating a Global Mindset for Sustainability}

A Global Mindset is viewed as essential for meeting the strategic challenges for global leadership [121,122]. Drawing from being-centered leadership theory, Egel and Fry [23,25] proposed that foundational to cultivation of a GM are five levels of being (Levels V-I). Each level encompasses the leader's experience of the world, their core beliefs and values, and life in general and, through this filter, the leader's ontological experience of reality and the 
epistemological context for how they cognitively know their reality for decision making and subsequent behavior.

At Level V, leaders have self-concepts and identities focused on "having" or "doing" in the physical and observable world through their five senses. Success is measured materially. The leader creates and transfers knowledge through active engagement in worldly affairs. Effective leadership requires developing appropriate diagnostic tools to discern the characteristics of tasks, subordinates, and the organization, and to adapt leadership behavior to produce effective outcomes. Level IV Leadership involves using images and imagination, such as creating a compelling vision or establishing strong cultural values, with an emphasis on subjective experience of individuals and groups as they develop awareness and knowledge. Effective leadership at this level creates consensus on a socially constructed reality, intrinsically motivating followers to attain higher levels of commitment and performance. The focus is on leaders' legitimacy, vision, and the ethical and cultural values which individuals and groups should embrace or reject. However, leadership at this level is organizationally-focused and ultimately self-serving.

A Global Mindset for Sustainability (GMS), is only possible when leaders are operating more consistently from Levels III and II, as it is only at these levels that leaders begin to realize the futility of the self-centered and materialistic way of life at levels V and IV, and the lack of meaning and suffering inherent in it [21]. At Level III, leaders become committed to being rather than having and doing. They begin to cultivate a spiritual practice (e.g., daily routine of prayer, mediation, reading, or similar action) dedicated to facilitating a spiritual journey of self-transcendence and interconnection that does not simply focus on enriching themselves with the trapping of success and financial stakeholders. As a result of their commitment to a spiritual practice, leaders become more other-centered, developing the capacity to be more aware, in the moment, of their experiences, thoughts, feelings, and body sensations (often termed mindfulness). Self-awareness and self-transcendence begin to emerge and become more dominant.

Building upon their commitment to the spiritual journey in Level III, Level II leaders are more consistently able, through self-transcendence and a sense of connectedness with all existence, to love and serve others. They are more able to embrace all stakeholders' perspectives and respect the fundamental dignity and worthiness of their fellow humans, other sentient beings, and nature. They are not threatened by other cultural standards or religions, seeing diversity as just another way of expressing people's similarities and unity as human beings on a spiritual journey.

Finally, leaders at level I perceive a transcendent unity. This stage of being that is more aspirational rather than a current reality within organizational settings. Few, if any, Level I leaders reside or work within organizational contexts. The world's wisdom traditions refer to this level of being as so all-encompassing that it contains both pure emptiness and pure fullness or completeness. At this level is the experience of transcendence of all opposites (dualities) and the realization of self-actualization. Separations dissolve and there is no distinction between the "leader" and the "led".

\subsubsection{Ethics for Sustainability}

As leaders operate more consistently from Levels III and II, two ethical principles become paramount. These work to extend the firm's interests beyond a primary emphasis on satisfying stakeholders interested in economic outcomes toward a more balanced, triple bottom line approach that extends moral responsibility to the social and environmental pillars of sustainable development: (1) remote moral responsibility to stakeholders that are distant in time and space, and (2) the acceptance of stakeholder legitimacy from a moral point of view that is grounded in care and compassion. They also challenge the current, most common norms of moral business conduct created by contemporary neoliberal economic theories [123]. Bringing these ethical principles to the forefront is essential, as they legitimize global leaders' choice for sustainability and offer a specific framework for enacting GLfS. 


\section{Remote Moral Responsibility}

A GMS expands the organization's moral imagination and obligation to assume remote responsibility for the impact of its actions and repercussions on stakeholders distant in time and context from direct organizational interests, including future generations. Here we define moral imagination as the "ability to imaginatively discern various possibilities for acting in a given situation and to envision the potential help and harm that are likely to result from a given action" [124] (p. 202). Moral imagination involves an active exploration of the situation and of possible actions. It offers an idealized standard- either internal, such as an ideal self-image, or external such as a moral exemplar-to evaluate an anticipated course of action. It encompasses both the creative ability to "disengage us from the dominant perspective (e.g., maximize profit) from which we view a situation so that we will be able to consider new possibilities" and a sense of moral awareness where one can then "evaluate these possibilities in terms of their moral worth" (p. 9). People who live in countries of the Global South are an example of stakeholders who are distant in space. Here are included employees in Africa, Asia, or Latin America who extract resources and manufacture the goods developed nations buy, yet are disenfranchised from a living wage or safe working conditions.

The questions global leaders for sustainability might ask through this ethical principle are: Who is worthy of our care and attention? Who are we responsible for? In other words, who is being morally excluded? As defined by Opotow [125] moral exclusion occurs "when individuals or groups are perceived as outside the boundary in which moral values, rules and considerations of fairness apply" (p. 1). If acting ethically is concerned with the way in which the rights, desires, and aspirations of others are balanced against our own, then it is vital to determine "who the other is". Generally speaking, people who are closer to us through kinship bonds or other aspects of psychological identification are easier to include in our circle of moral imagination. However, in addition to key stakeholders, global leaders for sustainability must also recognize that the socially disenfranchised, other sentient beings, and the earth are worthy of moral imagination and consideration [126]. Through GLfS, those outside this boundary are given full consideration as moral claimants. They are worthy of being included in the organizations strategic deliberations concerning the interplay among economic, social, and environmental forces for sustainable development.

\section{Acceptance of Stakeholder Legitimacy from a Moral Point of View}

Acceptance of stakeholder legitimacy from a moral point of view provides us with the framework within which we may exercise our moral imagination. Stakeholder legitimacy is not determined by whether stakeholders have power to voice their claims and pressure the corporation, or whether the corporation considers them important. Rather, it speaks to the organization's moral obligation to protect the rights of those stakeholders who are not in a position of power to claim and protect their rights [43]. Indigenous people in the Amazon rainforests whose survival is being threatened by deforestation and willful extraction of crude oil from cartels is an example of such a stakeholder $[23,73,127]$.

As the philosopher Hans Jonas [128] described it, future human beings, other sentient beings, and the Earth do not have rights. Our duty to future generations and to nature are independent of any idea of a right or reciprocity or justice. That fulfilling our human responsibility to guard both powerless and future stakeholders requires an expansion of our ethical perception of justice to an ethical perception of care [129]. Moral reasoning based on justice is predicated on impartiality, fairness, reciprocity, and the application of universal moral principles to abstract features of ethical situations [130]. An ethics of care entails having certain dispositions and feelings with a focus on sympathy, compassion, and concern for the well-being of all [131,132].

Martin Heidegger [133] talks about care as attention to one's presence in the world. It is not just about the leader's or organization's self-interests, it is also about attention, solicitude, and active involvement with other powerless stakeholders that are morally relevant in terms of distance in time or space. Stakeholder legitimacy from a moral point 
of view is not determined by whether stakeholders have power to voice their claims and pressure the corporation, or whether the corporation considers them important, but rather the assumption that this is a right based on the fundamental dignity of all humans, sentient beings, and nature.

\subsection{Leadership for Sustainability}

Referencing Figure 1, leaders for sustainability must cultivate a global mindset for sustainability by leading consistently from Levels of Being III and II and the two ethical principles that are necessary for cultivating a GMS. It is this higher level of consciousness that is the source of leadership for sustainability through hope/faith in a vision for sustainability and sustainable development and an organizational culture based on the values of altruistic love.

\subsubsection{Altruistic Love}

GLfS draws on the cultural values of altruistic love as defined through spiritual leadership theory, which is "a sense of wholeness, harmony, and well-being produced through care, concern, and appreciation for both self and others" [108] (p. 712). Underlying this definition are cultural values such as integrity, patience, kindness, forgiveness, acceptance, gratitude, humility, courage, trust, loyalty, and compassion, which facilitates a sense of interconnectedness among all stakeholders. A culture that invites all stakeholders to come together in support of a common commitment and passion for sustainability and sustainable development [21]. This is critical because organizations operating in today's complex, dynamic, and interdependent world requires cooperating, rather than competing, with stakeholders in order to sense and shape the external environment, source and seize innovative opportunities, and adapt to changing conditions.

\subsubsection{Vision}

Visions are inspirational. They define the organization's journey, what it aspires to be, and why the leaders and followers are taking it. In mobilizing stakeholders, vision should have broad appeal, define the organization's destination and journey, encourage hope and faith, reflect high ideals, and establish a standard of excellence [134,135]. Because of intense global competition, shortened development cycles for technology, and strategies losing their competitive advantage quickly, it is of utmost importance for GLfS that a clear compelling, vibrant, and idealized vision for sustainability and sustainable development be co-created through the involvement of all relevant stakeholders as a beacon for where the organization wants to be going forward, with a persuasive reason for why people should strive to create that future.

\subsubsection{Hope/Faith}

Hope/Faith is the unwavering commitment to the organization's vision for sustainability and sustainable development. It results from the conviction that sustainability is the only way forward; the only chance we have to survive and thrive. It is sourced in an inner knowing that goes beyond profit and loss statements and creates a foundation of trust for pursuing the vision. Often the metaphor of preparing for and running a race is used to describe faith as an expectation of reward or victory the joy of preparing for and seeing the race as a vision quest [136]. Hope/Faith acts as the motivational force that fuels the vision and sustains the culture of altruistic love. Discussing the importance of faith in soldiers, Sweeney, Hannah, and Snider [137] (p. 33) state that "faith is critical because it provides the direction and will to persist in the continuous, often arduous, journey of life and the trust and hope that the journey will produce a life worth living". We see this as a direct analogy to the role Hope/Faith plays as an intrinsic motivational force in GLfS. 


\subsection{Spiritual Well-Being}

Referencing Figure 1, leadership for sustainability then positively influences spiritual well-being as leaders model the values of altruistic love to co-create hope/faith in pursuit of a common vision for sustainability to love and serve key stakeholders. There are two primary aspects of spiritual well-being [21]: (1) a sense of transcendence, purpose, or being called (vocationally) to be a change agent for sustainability, which gives one a sense that one's life has meaning and makes a difference and (2) a sense of membership, belonging, and community, whereby both leaders and followers feel understood, appreciated, and supported for their dedication to sustainability and sustainable development.

\subsubsection{Calling}

It is through calling that one finds this miraculous transformation that is the source of one's commitment to an authentically purposeful life that provides meaning and turns work into an effortless privilege [138]. There is something inherent to the human experience that speaks to the universal yearning for a calling grounded in a sense of purpose; for a vocation that fulfills the world as it moves forward in one's own life; for a role that interlocks with the roles of others. Calling emerges through experiences where one learns that true happiness cannot be found through external gifts or the trappings of success. A strong sense of purpose provides the commitment and strength for facing doubts limitations, and self-contradictions head on while fighting distraction, futility, rationalization, and fatigue at every step; to rise above one's circumstances to care about something or someone beyond oneself [26].

Carl Jung, the founder of analytical psychology, believed the process of discovering ones calling has two stages. There is first an inner voice, a call to vocation that has the power of a law or God. This is followed by a free choice to obey the call. He believed that through calling one discovers and fulfills their deep true potential, much as the acorn has the potential to become the oak, or the caterpillar to transform into a butterfly. Based on his study of both eastern and western religions, Jung thought the spiritual experience of discovering ones calling and, therefore, one's purpose, gives life meaning and is essential to our well-being. It is a journey to meet the self and at the same time to meet the Divine $[27,139]$.

A purpose for sustainability is a powerful source of intrinsic motivation and this purpose can only be found through going inward to find a source of strength or power greater than ourselves to have hope/faith in a vision of loving and serving others, whether it be family, friends, or an organization (e.g, NGOs focused on sustainability). This is the very essence of and goes to the heart of sustainability and sustainable development [21]. Note that the recent manifesto from the Business Roundtable proclaimed the sole pursuit of profits and shareholder wealth is no longer the main purpose of business, but rather now leaders and their organizations must heed the call to have a more positive influence on society and the environment [140].

\subsubsection{Membership}

Membership is the universal need for belonging and community within which one is understood, appreciated, accepted, and supported for who we are just as we are, warts and all. Membership enables compassionate identification with others in community and fellowship that helps to heal isolated individuals. It becomes the source of personal ethics and leads to codes of conduct based on the universality of pain and suffering. This sense of membership plays a vital role in fostering resilience, happiness, and well-being. It also provides the context for how and to whom we communicate, the language we use as well as what thoughts we think [21].

Membership at work requires an organizational culture based on the values of altruistic love so there is sense of mutual caring, support, and being connected to each other as part of a larger community based on mutual acceptance and trust. Membership in a supportive community helps change agents for sustainability feel they are important, 
that they have value, and that they belong while experiencing deep communion with others, which eventually expands beyond humanity toward a sense of membership in the community of all living things.

In this sense our physical and psychological lives are ecological in that our values, thoughts, possessions, health, and even the food we eat and the air we breathe are interconnected lattices of webs reaching from person to person. As we weave these webs, we define the reality of our lived-in universe. These realities are not spun alone; they overlap in multilayered depths in the sea of intersecting human worlds of work, family, community, the socially disenfranchised, and the natural environment so necessary for our spiritual well-being.

\subsection{Triple Bottom Line Outcomes}

The triple bottom line measures the impact of an organization's sustainability initiatives on the world, including its profitability and shareholder value, employee well-being, and its social and environmental impact. Here we propose that, through the lens of the three pillars of sustainability, positive triple bottom line personal, organizational, and stakeholder outcomes are the result of satisfying employees' fundamental needs for spiritual well-being. When members of an organization have a commitment to a common purpose for sustainability and a sense of belonging in a community supportive of sustainability, the organization, as a whole, is more successful in meeting or exceeding stakeholder expectations focused on sustainable development [21,22].

In terms of tangible outcomes, the three pillars of sustainability represented through the triple bottom line provide the lens through which leaders and their organization assess stakeholder satisfaction and organizational success through development of key performance indicators (KPIs). Examples include also see [141,142]:

- economic-organizational commitment and productivity, total revenue, net profit, ROI, ROE, environmental compliance, environmental costs savings, sustainable innovations rate, environmental certifications (e.g., ISO 14000);

- social-employee well-being, diversity and inclusion metrics, percent participants in social initiatives, consumer, supplier, and employees' safety rate, investment, and procurement practices;

- environmental-carbon footprint, percent reusable/recycled material, energy intensity (energy used per thousand product units), sustainable water use rate.

Thus, focusing on the KPIs comprising the triple bottom line can be an important tool for GLfS in achieving the organization's sustainable development goals.

\section{Comparison of Leadership for Sustainability Models}

Here we demonstrate that GLfS incorporates and extends the conceptual domain of the three most widely cited approaches to leadership for sustainability reviewed earlier (see Table 2, Column 1). Table 2 also highlights the degree to which sustainability leadership, responsible leadership, and conscious leadership either explicitly, implicitly, or fail to incorporate elements of the GLfS model.

Common to sustainability leadership, responsible leadership, conscious leadership, and GLfS is an explicit emphasis on leadership of change agents for sustainability through a multi-level, stakeholder engagement strategy. They all also emphasize engagement with key stakeholders to co-create a vision for sustainability with a shared purpose that acts to galvanize and nurture an inclusive and relational community, with a focus on triple bottom line outcomes centered on the economic, social, and environmental pillars of sustainability and sustainable development. However, only responsible leadership has seen causal models tested that explicitly specify antecedents and outcomes $[87,91,94]$. Similarly, only one study on sustainability leadership has explicitly proposed that sustainability leadership is essential for implementing a learning organizational paradigm [60]. Likewise, only conscious leadership explicitly speaks to the major role love must play in fostering employee, social, environmental as well as economic well-being [48]. 
Table 2. Comparison of Leadership for Sustainability Models.

\begin{tabular}{|c|c|c|c|c|}
\hline Leadership for Sustainability Conceptual Domain & $\begin{array}{l}\text { Sustainability } \\
\text { Leadership }\end{array}$ & $\begin{array}{c}\text { Responsible } \\
\text { Leadership }\end{array}$ & Conscious Leadership & $\begin{array}{l}\text { Global Leadership } \\
\text { for Sustainability }\end{array}$ \\
\hline Causal Model & & Explicit & & Explicit \\
\hline Learning Organization & Explicit & implicit & implicit & Explicit \\
\hline Stakeholder Focused & Explicit & Explicit & Explicit & Explicit \\
\hline Multi-Level & Explicit & Explicit & Explicit & Explicit \\
\hline Change Agent & Explicit & Explicit & Explicit & Explicit \\
\hline $\begin{array}{l}\text { Spiritual Foundation: } \\
\text { Mindfulness } \\
\text { Self-Transcendence } \\
\text { Interconnectedness }\end{array}$ & Implicit & Implicit & Implicit & Explicit \\
\hline Global Mindset for Sustainability & & & & Explicit \\
\hline Visionary & Explicit & Explicit & Explicit & Explicit \\
\hline Altruistic Love & Implicit & Implicit & Explicit & Explicit \\
\hline Two ethical Dimensions for sustainability & & & & Explicit \\
\hline Calling/Purpose & Explicit & Explicit & Explicit & Explicit \\
\hline Inclusive and Relational & Explicit & Explicit & Explicit & Explicit \\
\hline Triple Bottom Line & Explicit & Explicit & Explicit & Explicit \\
\hline
\end{tabular}

Other components of the GLfS model are implicitly referred to in research on sustainability, responsible, and conscious leadership. Spirituality in terms of reflexive, mindful practices that facilitate being present and conscious moment-to-moment is implicitly emphasized in all three of these approaches to leadership for sustainability. However, none explicitly refer to the relationship between these spiritual practices and how they result in or produce the commitment to self-transcendence and interconnectedness seen to be essential for sustainability. Sustainability leadership and responsible leadership emphasize that leadership for sustainability embrace altruistic, caring ethical values. Organizational learning is generally implied in studies on responsible and conscious leadership. Finally, no studies on leadership for sustainability have explored the process for cultivating a GMS. Nor have they explored the ethical principles necessary for sustainability that also result from cultivating a global mindset for sustainability.

As shown in Table 2, GLfS incorporates and explicitly extends the conceptual domain of the three most widely cited approaches to leadership for sustainability reviewed earlier. Following the logic of the causal model of GLfS given in Figure 1, GLfS links spirituality, as defined through self-transcendence and interconnectedness, to sustainability through a global mindset for sustainability that incorporates two ethical principles for sustainability, which embrace remote moral responsibility and acceptance of stakeholder legitimacy through an ethic of care. It is also a multi-level model for organizational transformation to a learning organizational paradigm that is seen to facilitate vision and value congruence across the individual, empowered team, organization, and stakeholder levels. GLfS then intrinsically motivates and inspires change agents for sustainability through hope/faith in a vision for sustainability and a corporate culture based on altruistic love, which then satisfies both leader's and follower's need for spiritual well-being through a sense of purpose or calling, to be a change agent for sustainability and a sense of belonging or membership in an inclusive and relational community for sustainable development. Satisfying these needs for spiritual well-being focused on sustainability then positively influences employee wellbeing, and the economic, social, and environmental outcomes for sustainability represented through the triple bottom line outcomes.

\section{Discussion}

The GLfS model is proposed as a universal model. In other words, the spiritual qualities of transcendence and interconnectedness, a Global Mindset for Sustainability, 
the two ethical principles for sustainability, vision for sustainability, and cultural values based on altruistic love are viewed as necessary for sustainability, sustainable development, and implementation of the triple bottom line key indicators. GLfS requires leaders with extraordinary decision-making and problem-solving skills, as these organizations must operate within complex interconnected and dynamic environmental, economic, and social systems [143]. This has significant implications for the theory, research, and practice of GLfS.

\subsection{Implications for Theory and Research}

As we demonstrated though Table 2, GLfS extends the conceptual domain beyond current approaches to leadership for sustainability. We consider this approach most relevant as the field of global leadership primarily focuses on a set of business skills that global leaders generally rely on for creating strategy $[15,111-114]$. Sustainability, on the other hand, offers the lens through which global leadership for sustainability should be enacted. Up to this point, research on leadership for sustainability as well as on leadership approaches that incorporate sustainability have not explicitly encompassed the global dimension as represented through GMS.

Also, incorporating two ethical principles necessary for sustainability provide the foundation for GMS as the existential reality that is the source for GLfS. Leaders with deeply held beliefs concerning the welfare of human and sentient being and nature are more likely to develop sustainability-based ethical systems to guide their strategic decision making and actions. They will support stakeholders that represent the best interests of the planet and its people, respond to their concerns, and consciously work to develop and improve the sustainability-based capabilities of the organizations they lead [22].

In this sense, GMS offers a new mode of meaning making; a new schema (structure/framework) through which awareness is organized [144]. Schemas play an important role in the identification of ethical issues as they organize what we pay attention to and our ability to spot the ethical aspect of a situation. Without these to alert us to ethical concerns related to sustainability and sustainable development, leaders are unlikely to notice when ethical issues arise and to judge the moral quality of their actions. The current, most common bases for norms of moral business conduct are the ones created by contemporary rule-based theories that include formulations such as utilitarianism, justice, and rights/duties [123]. They place a premium on individual autonomous choice and equality and encompass notions of balancing rights and responsibilities driven by merit [145]. However, in order to maximize the triple bottom line, global leaders for sustainability need to adopt different schemas, grounded in an ethic of care, which will legitimize their choice for sustainability over profit making alternatives [146,147]

Moreover, as it is grounded SLT and incorporates and extends current approaches to leadership for sustainability, the GLfS model provides for a more focused, reliable, and valid research approach than the current extant research on sustainable and responsible leadership. Perhaps most importantly, GLfS, like SLT, which has been extensively tested and validated $[109,110]$, is posed as a causal model that can be tested empirically through rigorous quantitative methods as well as explored through qualitative research.

\subsection{Implications for Practice}

We have proposed that since sustainability is deeply rooted in the fundamental dignity of human and sentient beings and all of nature, building spiritual capabilities is essential and necessary for the practice of GLfS [22]. Given that spiritual leadership theory provides the theoretical foundation for GLfS, it provides a natural starting point for exploring the practice of GLfS, as the practice spiritual leadership at both the personal and organizational levels has been extensively explicated (c.f., [21,23,148-151]). However, as space limitations allow only for a general summary here, the reader is referred to the above citations for more detail. 


\subsubsection{Cultivating a Global Mindset for Sustainability}

Leaders who cultivate a GMS seek self-transcendence and interconnection with all human and sentient beings and the natural world. However, these qualities are only manifest at the Levels III and II of being. At these levels, global leaders for sustainability exhibit higher levels of consciousness, self-awareness, deeper empathy, compassion, and othercenteredness as well as greater awareness of the needs of their colleagues, organizations, communities, relevant stakeholders, and how all these interrelate. Leaders who have embraced their vulnerability and weaknesses are better able to successfully address conflicting stakeholder demands and strategic complexity, including the integration of geographically distinct operations and markets, while simultaneously responding to local demands.

In cultivating a GMS, global leaders for sustainability and their organizations also come to embrace the two ethical principles we view as necessary for true commitment to sustainable development, as it serves to reinforce a moral schema that will legitimize dedication to sustainability over strategies that solely focus on enriching top management and profit-seeking stakeholders [146,147]. It is only by deeply ingraining into the organization's culture remote moral responsibility and stakeholder legitimacy from a moral point of view, much as was done by Paul Polman during his tenure as CEO of Unilever [152], that the fundamental dignity of disenfranchised social and environmental stakeholders is deemed worthy of care, moral deliberation, and strategic attention in decision making.

Most important for cultivating a GMS is for leaders to develop an effective a spiritual or meditative practice as this provides the gateway to the Levels III and II way of being [21,153-155], which may be facilitated through a company sponsored executive coach $[150,156]$. However, it is important to note that most organizations prefer a neutral term, such as mindfulness training, since people tend associate the word spiritual with religion. Because of this, it has proved challenging to balance employee and employer's expression of belief without judgment with respective parties' legal rights [109].

In addition to mindfulness training for leaders, fostering voluntary programs that nurture employees' GMS is necessary for establishing GMS across the organization [21,157] including management practices such as:

- company-wide mindfulness training programs [157];

- developing a personal mission statements, which provide both the foundation and guidance for GLfS;

- a brief moment of silence before meetings;

- a room for silence;

- $\quad$ spiritual support groups;

- corporate chaplains/spiritual directors for confidential inner spiritual guidance and support;

- $\quad$ providing employees with coaching and mentoring opportunities for both technical and leadership development and formation;

- $\quad$ supporting a context for conversations among workers about personal fulfilment and spiritual aspirations;

- a library that loans spiritual and religious materials.

\subsubsection{Leadership for Sustainability Through Hope/Faith, Vision, and Altruistic Love}

Implementing leadership for sustainability through hope/faith in a vision for sustainable development and a strong organizational culture based on the values of altruistic love entails developing effective relationships between the organization and environmental stakeholders. This requires selectively recruiting new personnel who identify with the company's vision and values, an organizational design based on empowered teams and decentralized decision making, and competitive compensation that is contingent upon organizational performance, transparency of financial and performance information, and reduced positional status distinctions and barriers.

To facilitate this process, several ongoing organization development (OD) interventions are critical for the implementation of GLfS [21]: 
- $\quad$ administer GLfS Survey to establish a baseline and raise key issues (See Appendix A) [158];

- conduct vision/stakeholder analysis;

- the organization's leadership team, in conjunction with representatives from all relevant stakeholders, work to co-create the organization's vision and mission, utilizing cultural values based on altruistic love and the two ethical principles for sustainability as a foundation;

- identify stakeholder expectations;

- develop stakeholder effectiveness criteria to meet these expectations;

- identify issues for each stakeholder that fail to meet these criteria;

- organize and create empowered teams/task forces around key issues;

- develop goals and strategies to address these issues;

- develop stakeholder information systems to measure effectiveness;

- conduct organizational development interventions and skills training;

- develop elements of team empowerment;

- Employ collaborative, consensus-based decision making;

- manage conflict through conflict styles training and third-party confrontation, intergroup, and large group conflict interventions;

- manage and overcoming resistance to change;

- address workplace anger, resentment and fear through interventions that target the cultural values of forgiveness, acceptance, and gratitude;

- align changes with organization design variables, including, structure, information technology, production/service technology, promotion, and reward systems, and recruiting, selection and training processes.

To the extent these OD interventions are successfully put into practice, leaders for sustainability are better able to initiate active dialog, whereby, through a common vision, all affected stakeholders can reach balanced and fair decisions grounded in the two ethical principles for sustainability. They embrace the inevitability of continually changing organizational dynamics, while working within an action framework that provides for clear accountability and flexibility, recognizing that change and the conflict it creates fuels new ideas, discoveries, and innovations that can renew organizations, communities, and the earth.

Global leaders for sustainability also seek to continually expand their awareness and experiment with how to engage in any situation, respecting the value of individuals and stakeholders through their similarities and interconnectedness to others, all life and nature, as well as through their diversity and distinctiveness. They make informed decisions and take calculated risks, learn from mistakes, and share what they discovered in the process, avoiding the ego-driven certainty of "right" answers but rather genuinely engage others in the decision-making process in the interest of mutual gain. In doing so they become role models that attract others to commit to sustainability and sustainable development.

\section{Conclusions}

GLfS can be practiced by leaders who seek sustainable change, regardless of role or position, to build the kind of world that we want our children and grandchildren to inherit [20]. In its broadest sense, sustainability and sustainable development mean that all humans not only live beyond mere biological survival but also have the fundamental right to experience a sense of purpose and meaning within a loving community, with leaders committed to a sustainable world that insures not just the status quo but the flourishing of future generations [38]. Leaders and their organizations should have a higher purpose beyond enriching themselves and financial stakeholders. In addition to economic success, leaders have responsibility for the well-being of employees, their communities, the socially disenfranchised, and the earth we all inhabit. We should all leave, as part of our legacy, a sustainable, flourishing world for our children, grandchildren, and future generations to come. 
This unparalleled challenge requires an unprecedented approach to leadership, which is perhaps the greatest test facing humanity and the organizations they create, to foster a more socially responsible, sustainable world within an economic system based on the fundamental dignity of human and sentient beings with compassion for the Earth we all inhabit. GLfS recognizes that we can all fill this role regardless of our location in or the size of the organization. However, GLfS requires spiritually conscious, visionary, ethically oriented, inclusive, and results driven change agents [23,53,143,159]. To equip these leaders for this task, we have offered a comprehensive domain that must be mastered for effective GLfS. This is a leadership paradigm in which leaders experience purpose within a community committed to something greater than themselves. If we are willing to walk this path of spiritual discovery; if we are in it for the long haul and we approach the journey with a great spirit of creativity and mutual benefit; and if we care deeply for ourselves and those we share the journey with, we will become true change agents for sustainability to the benefit of our lives, our organizations, and our world.

Author Contributions: Both authors contributed equally. All authors have read and agreed to the published version of the manuscript.

Funding: This research received no external funding.

Institutional Review Board Statement: Not applicable.

Informed Consent Statement: Not applicable.

Data Availability Statement: Data sharing not applicable.

Conflicts of Interest: The authors declare they have no conflicts of interest.

Appendix A

Global Leadership for Sustainability Survey

I. Global Mindset for Sustainability-the extent to which one seeks mindful awareness or presence in the now (Level of Being III). *

1. _ (Q6) I do jobs or tasks automatically, without being aware of what I'm doing.

2. _ (Q18) I find it difficult to stay focused on what's happening in the present.

3. _ (Q30) I could be experiencing some emotion and not be conscious of it until sometime later.

4. _ (Q42) I find myself doing things without paying attention.

5. _ (Q50) I forget a person's name almost as soon as I've been told it for the first time.

* These items are reverse scored $(5=1,4=2,3=3,2=4,5=1)$.

Total Score $/ 5=$

\section{Leadership for Sustainability}

Vision-describes the organization's journey and why we are taking it; defines who we are and what we do.

1. _ (Q1) My company has a vision for a sustainable world that brings out the best in me.

2. (Q13) My organization's vision for sustainability inspires my best performance.

3. (Q25) My organization has a vision for sustainability that I am committed to.

4. _ (Q37) My organization's vision for sustainability is clear and compelling to me.

Total Score $/ 4=$

Hope/Faith-the assurance of things hoped for, the conviction that the organization's vision/purpose/mission will be fulfilled.

1. (Q2) I have faith in my organization and I am willing to "do whatever it takes" to ensure that it accomplishes its vision for sustainability. 
2. (Q14) I demonstrate my faith in my organization and its vision for sustainability by doing everything I can to help us succeed.

3. _ (Q26) I persevere and exert extra effort to help my organization succeed because I have faith in its commitment to sustainability.

4. ___ (Q38) I set challenging goals for my work because I have faith in my organization's vision for sustainability and want us to succeed.

Total Score $/ 4=$

Altruistic Love-a sense of wholeness, harmony, and well-being produced through care, concern, and appreciation for both self and others.

1. _ (Q3) The leaders in my organization" walk the walk" as well as "talk the talk".

2. __ (Q15) The leaders in my organization are honest and without false pride.

3. _ (Q27) My organization is trustworthy and loyal to its employees.

4. _ (Q39) The leaders in my organization have the courage to stand up for their people.

5. _ (Q49) My organization is kind and considerate toward its workers, and when

they are suffering, want to do something about it.

Total Score $/ 5=$

\section{Spiritual Well-Being}

Meaning/Calling-a sense that one's life has purpose, meaning, and makes a difference.

1. (Q4) The work I do related to sustainability makes a difference in people's lives.

2. _ (Q16) The work I do is meaningful to me.

3. __ (Q28) The work I do is very important to me.

4. __ (Q40) My job activities related to sustainability are personally meaningful to me.

Total Score $/ 4=$

Membership-a sense that one is understood and appreciated.

1. _ _ (Q5) I feel my organization appreciates me and my work for sustainability.

2. __ (Q17) I feel my organization demonstrates respect for me and my passion for sustainability.

3. ___ (Q29) I feel I am valued as a person in my job.

4. __ (Q41) I feel highly regarded by my leaders.

Total Score $/ 4=$

\section{Triple Bottom Line}

\section{Economic}

Organizational Commitment-the degree of loyalty or attachment to the organization.

1. _ (Q7) I really feel as if my organization's problems are my own.

2. _ _ (Q19) I would be very happy to spend the rest of my career with this organization.

3. _ (Q31) I talk up this organization to my friends as a great place to work.

4. __ (Q43) I feel a strong sense of belonging to my organization.

Total Score $/ 4=$

Productivity-Work group efficiency in producing results, benefits, or profits.

1. _ (Q8) In my department, everyone gives his/her best efforts.

2. _ (Q20) In my department, work quality is a high priority for all workers.

3. _ (Q32) My work group is very productive.

4. _ (Q44) My work group is very efficient in getting maximum, output from the resources (money, people, equipment, etc.) we have available.

Total Score $/ 4=$

\section{Organizational Economic Factors}

1. _ (Q11) My organization is recognized for the service given to its customers.

2. __ (Q23) My organization is recognized for the quality of its products/services. 
3. (Q35) My company is recognized as being financially successful.

4. _ (Q47) My organization actively controls the costs of operating (e.g., supply chain, recycling).

5. __ (Q52) My company closely monitors employee productivity and efficiency.

Total Score $/ 5=$

\section{Social}

Satisfaction with Life-one's sense of subjective well-being or satisfaction with life as a whole.

1. _ (Q9) I am satisfied with my life.

2. _ (Q21) In most ways my life is ideal.

3. _ (Q33) If I could live my life over, I would change almost nothing.

4. _ (Q45) So far, I have gotten the important things I want in life.

Total Score __ $/ 4=$

\section{Social and Stakeholder Responsibility}

1. (Q10) My organization believes that it has an obligation to serve the community in which it operates.

2. _ (Q22) My organization is committed to being socially responsible.

3. (Q34) My organization considers the consequences of its decisions on affected stakeholders.

4. ___ (Q46) My organization weighs different stakeholder interests before making a decision.

5. (Q51) My organization demonstrates awareness of the claims of social and environmental stakeholders.

Total Score $/ 5=$

\section{Environmental}

1. __ (Q12) My organization seeks to assess the impact our operations on the environment.

2. __ (Q24) My company is recognized for working to minimizing its environmental impact.

3. (Q36) My organization has adopted specific initiatives to reduce its environmental impact.

4. _ـ (Q48) My company has a program in place to reduce the amount of energy and materials wasted in our business.

5. _ _ (Q53) My organization's leaders are committed to environmental sustainability.

Total Score $/ 5=$

\section{References}

1. Orr, D. Four challenges of sustainability. Conserv. Biol. 2002, 16, 1457-1460. [CrossRef]

2. Alon, I.; Higgins, J.M. Global leadership success through emotional and cultural intelligences. Bus. Horiz. 2005, 48, 501-512. [CrossRef]

3. Maak, T.; Borecká, M.; Pless, N.M. Developing global leaders who make a difference. In Research Handbook of Global Leadership; Zander, L., Ed.; Edward Elgar Publishing: Cheltenham, UK, 2020; pp. 251-265.

4. Brannen, M.Y.; Salk, J.E. Partnering across borders: Negotiating organizational culture in a German-Japanese joint venture. Hum. Relat. 2000, 53, 451-487. [CrossRef]

5. Chomsky, N. Explaining language use. Philos. Top. 1992, 20, 205-231. [CrossRef]

6. Fiol, C.M. A semiotic analysis of corporate language: Organizational boundaries and joint venturing. Adm. Sci. Q. 1989, 34, 277-303. [CrossRef]

7. Lauring, J.; Selmer, J. Multicultural organizations: Common language and group cohesiveness. Int. J. Cross Cult. Manag. 2010, 10, 267-284. [CrossRef]

8. Mäkelä, K.; Lauring, J.; Butler, C.L.; Lee, H.J.; Lücke, G.; Miska, C.; Pahlberg, C.; Stahl, G. Meeting the challenges of globalization in order to make a difference: Implications for teams and team leadership. In Research Handbook of Global Leadership; Zander, L., Ed.; Edward Elgar Publishing: Cheltenham, UK, 2020; pp. 91-108. 
9. Towards the Circular Economy. Available online: https://www.ellenmacarthurfoundation.org/assets/downloads/publications / TCE_Report-2013.pdf (accessed on 22 May 2019).

10. Living Planet Report 2012: Biodiversity, Biocapacity and Better Choices. Available online: https://wwfint.awsassets.panda.org/ downloads/lpr_living_planet_report_2012.pdf (accessed on 24 May 2021).

11. Living Planet Report 2014: Species and Spaces, People and Places. Available online: http:/ / assets.worldwildlife.org/publications / 723/files / original/WWF-LPR2014-low_res.pdf?1413912230\&_ga=2.11412404.1440958377.1621880970-486511296.1621880970 (accessed on 24 May 2021).

12. $50+20$ Agenda. Management Education for the World. Available online: http://grli.org/wp-content/uploads/2017/12/5020 -Agenda-English.pdf (accessed on 5 May 2020).

13. Better Business Better World. Business \& Sustainable Development Commission under Creative Commons License AttributionNonCommercial 4.0 International (cc by-nc 4.0). 2017. Available online: https:/ /d306pr3pise04h.cloudfront.net/docs/news_events\% 2F9.3\%2Fbetter-business-better-world.pdf (accessed on 11 November 2019).

14. Edelman Trust Barometer Finds a Crisis in Leadership. Available online: https://www.edelman.com/news-awards/2013 -edelman-trust-barometer-finds-crisis-leadership (accessed on 25 November 2019).

15. Jokinen, T. Global leadership competencies: A review and discussion. J. Eur. Ind. Train. 2005, 29, 199-216. [CrossRef]

16. Palazzo, B. US-American and German business ethics: An intercultural comparison. J. Bus. Ethics 2002, 41, 195-216. [CrossRef]

17. Roth, K.; Schweiger, D.M.; Morrison, A.J. Global strategy implementation at the business unit level: Operational capabilities and administrative mechanisms. J. Int. Bus. Stud. 1991, 22, 369-402. [CrossRef]

18. Mazutis, D.D. The CEO effect: A longitudinal, multilevel analysis of the relationship between executive orientation and corporate social strategy. Bus. Soc. 2013, 52, 631-648. [CrossRef]

19. Mazutis, D.; Zintel, C. Beyond corporate social responsibility: Global leadership virtues that make a difference. In Research Handbook of Global Leadership; Zander, L., Ed.; Edward Elgar Publishing: Cheltenham, UK, 2020; pp. 221-235.

20. Ferdig, M.A. Sustainability leadership: Co-creating a sustainable future. J. Chang. Manag. 2007, 7, 25-35. [CrossRef]

21. Fry, L.W.; Nisiewicz, M.S. Maximizing the Triple Bottom Line through Spiritual Leadership; Stanford University Press: Redwood City, CA, USA, 2013.

22. Stead, J.G.; Stead, W.E. Building spiritual capabilities to sustain sustainability-based competitive advantages. J. Manag. Spiritual. Relig. 2014, 11, 143-158. [CrossRef]

23. Egel, E.; Fry, L. Cultivating a global mindset through “Being-centered "leadership. In The Handbook of Personal and Organizational Transformation; Neal, J., Ed.; Springer International Publishing: New York, NY, USA, 2018; pp. 981-1000.

24. Kriger, M.; Seng, Y. Leadership with inner meaning: A contingency theory of leadership based on the worldviews of five religions. Leadersh. Q. 2005, 16, 771-806. [CrossRef]

25. Fry, L.; Kriger, M. Towards a theory of being-centered leadership: Multiple levels of being as context for effective leadership. Hum. Relat. 2009, 62, 667-696. [CrossRef]

26. Fairholm, G.W. Capturing the Heart of Leadership: Spirituality and Community in the New American Workplace; Greenwood Publishing Group: Santa Barbara, CA, USA, 1997.

27. Frankl, V.E. Man's Search for Meaning; Simon and Schuster: New York, NY, USA, 1985.

28. Koltko-Rivera, M. Rediscovering the later version of Maslow's hierarchy of needs: Self-transcendence and opportunities for theory, research, and unification. Rev. Gen. Psychol. 2006, 10, 302-317. [CrossRef]

29. Maslow, A. Peak experiences in education and art. Theory Into. Pract. 1971, 10, 149-153. [CrossRef]

30. Giacalone, R.A.; Jurkiewicz, C.L. Handbook of Workplace Spirituality and Organizational Performance; M.E. Sharpe: New York, NY, USA, 2003.

31. Macy, J. The ecological self: Postmodern ground for right action. In Sacred Interconnections; Griffin, D.R., Ed.; State University of New York Press: Albany, NY, USA, 1990; pp. 35-48.

32. The World Commission on Environment and Development: Our Common Future (The Brundtland Report). Available online: https:/ / sustainabledevelopment.un.org/content/documents/5987our-common-future.pdf (accessed on 10 July 2019).

33. Orr, D. Framing sustainability. Conserv. Biol. 2006, 20, 265-267. [CrossRef] [PubMed]

34. Leopold, A. A Sand County Almanac; Random House: New York, NY, USA, 1949.

35. Pruzan, P.; Pruzan-Mikkelsen, K.; Miller, D.; Miller, W. Leading with Wisdom: Spiritual-Based Leadership in Business; Greenleaf Publishing: Sheffield, UK, 2007.

36. Daly, H.E. Steady State Economics; W. H. Freeman: San Francisco, CA, USA, 1977.

37. Schumacher, E.F. Small is Beautiful: Economics as if People Mattered; Harper and Row: New York, NY, USA, 1973.

38. Brown, B.J.; Hanson, M.E.; Liverman, D.M.; Merideth, R.W., Jr. Global sustainability: Toward definition. Environ. Manag. 1987, 11, 713-719. [CrossRef]

39. Lazlo, C.; Brown, J. Flourishing Enterprise: The New Spirit of Business; Stanford University Press: Stanford, CA, USA, 2014.

40. Astin, A.; Astin, H. A Social Change Model of Leadership Development. Available online: https://www.heri.ucla.edu/PDFs/ pubs/ASocialChangeModelofLeadershipDevelopment.pdf (accessed on 20 December 2020).

41. Komives, S.R.; Lucas, N.; McMahon, T.R. Exploring Leadership: For College Students Who Want to Make a Difference; Jossey-Bass: San Francisco, CA, USA, 1998. 
42. Burns, H.; Vaught, H.; Bauman, C. Leadership for sustainability: Theoretical foundations and pedagogical practices that foster change. Int. J. Leadersh. Stud. 2015, 9, 131-143. Available online: https://pdxscholar.library.pdx.edu/cgi/viewcontent.cgi?article= 1044\&context=elp_fac (accessed on 25 February 2019).

43. Senge, P.; Hamilton, H.; Kania, J. The dawn of system leadership. Stanf. Innov. Rev. 2015, 13, 27-33. Available online: https://ssir.org/articles/entry/the_dawn_of_system_leadership (accessed on 8 April 2019).

44. SDG Knowledge Platform. Available online: https://sustainabledevelopment.un.org/ (accessed on 5 December 2019).

45. Maak, T.; Pless, N.M. Responsible leadership in a stakeholder society. J. Bus. Ethics 2006, 66, 99-115. [CrossRef]

46. Hallinger, P.; Suriyankietkaew, S. Science mapping of the knowledge base on sustainable leadership, 1990-2018. Sustainability 2018, 10, 4846. [CrossRef]

47. Marques, T.; Reis, N.; Gomes, J.F. Responsible leadership research: A bibliometric review. Bar. Braz. Adm. Rev. 2018, 15. [CrossRef]

48. Mackey, J.; Sisodia, R. Conscious Capitalism: Liberating the Heroic Spirit of Business; Harvard Business School Publishing: Boston, MA, USA, 2014.

49. Mackey, J.; McIntosh, S.; Phipps, C. Conscious Leadership: Elevating Humanity Through Business; Penguin Random House LLC: New York, NY, USA, 2020.

50. Avery, G.C.; Bergsteiner, H. Sustainable Leadership: Honeybee and Locust Approaches, 1st ed.; Allen \& Unwin: Sydney, Australia, 2011.

51. Hargreaves, A.; Fink, D. Sustainable Leadership; John Wiley \& Sons: Hoboken, NJ, USA, 2012.

52. Suriyankietkaew, S.; Avery, G. Sustainable leadership practices driving financial performance: Empirical evidence from Thai SMEs. Sustainability 2016, 8, 327. [CrossRef]

53. Knight, B.; Patterson, F. Behavioural competencies of sustainability leaders: An empirical investigation. J. Organ. Chang. Manag. 2018, 31, 557-580. [CrossRef]

54. Galpin, T.; Lee Whittington, J. Sustainability leadership: From strategy to results. J. Bus. Strategy 2012, 33, 40-48. [CrossRef]

55. Heizmann, H.; Liu, H. Becoming green, becoming leaders: Identity narratives in sustainability leadership development. Manag. Learn. 2017, 49, 40-58. [CrossRef]

56. Koskela, V.; Schuyler, K.G. Experiences of presence as a key factor toward sustainability leadership. J. Leadersh. Stud. 2016, 9, 54-59. [CrossRef]

57. Schein, S. Ecological worldviews: A missing perspective to advance global sustainability leadership. J. Manag. Glob. Sustain. 2015, 3, 1-24. [CrossRef]

58. Tideman, S.G.; Arts, M.C.; Zandee, D.P. Sustainable leadership: Towards a workable definition. J. Corp. Citizsh. 2013, 2013, 17-33. [CrossRef]

59. Wilson, S.G.; Kosempel, P. Introduction to the symposium on sustainability leadership. J. Leadersh. Stud. 2016, 9, 43-46. [CrossRef]

60. Wolfgramm, R.; Flynn-Coleman, S.; Conroy, D. Dynamic Interactions of Agency in Leadership (DIAL): An integrative framework for analyzing agency in sustainability leadership. J. Bus. Ethics 2015, 126, 649-662. [CrossRef]

61. Suriyankietkaew, S.; Avery, G.C. Employee satisfaction and sustainable leadership practices in Thai SMEs. J. Glob. Responsib. 2014, 5, 160-173. [CrossRef]

62. Avery, G.C. Leadership for Sustainable Futures: Achieving Success in a Competitive World; Edward Elgar Publishing: Cheltenham, UK, 2005.

63. Kantabutra, S.; Avery, G. Sustainable leadership: Honeybee practices at a leading Asian industrial conglomerate. Asia-Pac. J. Bus. Adm. 2013, 5, 36-56. [CrossRef]

64. McCann, J.; Holt, R. Servant and sustainable leadership: An analysis in the manufacturing environment. Int. J. Manag. Pract. 2010, 4, 134-148. [CrossRef]

65. Javed, A.; Iqbal, J.; Iqbal, S.; Imran, M. Sustainable leadership and employee innovative behavior: Discussing the mediating role of creative self-efficacy. J. Public Aff. 2020, e2457. [CrossRef]

66. Iqbal, Q.; Ahmad, N.; Nasim, A.; Khan, S. A moderated-mediation analysis of psychological empowerment: Sustainable leadership and sustainable performance. J. Clean. Prod. 2020, 262, 1-12. [CrossRef]

67. Doh, J.P.; Quigley, N.R. Responsible leadership and stakeholder management: Influence pathways and organizational outcomes. Acad. Manag. Perspect. 2014, 28, 255-274. [CrossRef]

68. Waldman, D.; Balven, R.M. Responsible leadership: Theoretical issues and research directions. Acad. Manag. Perspect. 2014, 28, 224-234. [CrossRef]

69. Miska, C.; Mendenhall, M.E. Responsible leadership: A mapping of extant research and future directions. J. Bus. Ethics 2018, 148, 117-134. [CrossRef]

70. Miska, C.; Hilbe, C.; Mayer, S. Reconciling different views on responsible leadership: A rationality-based approach. J. Bus. Ethics 2014, 125, 349-360. [CrossRef]

71. Freeman, R.E.; Auster, E.R. Values, authenticity, and responsible leadership. Responsible Leadersh. 2011, 98, 15-23. [CrossRef]

72. Pless, N.M. Understanding responsible leadership: Role identity and motivational drivers. J. Bus. Ethics 2007, 74, 437-456. [CrossRef]

73. Pless, N.M.; Maak, T.; Stahl, G.K. Developing responsible global leaders through international service-learning programs: The Ulysses experience. Acad. Manag. Learn. Educ. 2011, 10, 237-260. [CrossRef]

74. Voegtlin, C. What does it mean to be responsible? Addressing the missing responsibility dimension in ethical leadership research. Leadership 2014, 12, 581-608. [CrossRef] 
75. Voegtlin, C.; Patzer, M.; Scherer, A.G. Responsible leadership in global business: A new approach to leadership and its multi-level outcomes. J. Bus. Ethics 2012, 105, 1-16. [CrossRef]

76. Waldman, D.; Galvin, B. Alternative perspectives of responsible leadership. Organ. Dyn. 2008, 37, 327-341. [CrossRef]

77. Friedman, M. A Theoretical framework for monetary analysis. J. Political Econ. 1970, 78, 193-238. [CrossRef]

78. Friedman, M.; Friedman, R.D. Capitalism and Freedom; University of Chicago Press: Chicago, IL, USA, 2002.

79. Maak, T. Responsible leadership, stakeholder engagement, and the emergence of social capital. J. Bus. Ethics 2007, 74, 329-343. [CrossRef]

80. Pless, N.M.; Maak, T.; Waldman, D.A. Different approaches toward doing the right thing: Mapping the responsibility orientations of leaders. Acad. Manag. Perspect. 2012, 26, 51-65. [CrossRef]

81. Stahl, G.K.; de Luque, M. Antecedents of responsible leader behavior: A research synthesis, conceptual framework, and agenda for future research. Acad. Manag. Perspect. 2014, 28, 235-254. [CrossRef]

82. Székely, F.; Knirsch, M. Responsible leadership and corporate social responsibility: Metrics for sustainable performance. Eur. Manag. J. 2005, 23, 628-647. [CrossRef]

83. Han, Z.; Wang, Q.; Yan, X. How responsible leadership motivates employees to engage in organizational citizenship behavior for the environment: A double-mediation model. Sustainability 2019, 11, 605. [CrossRef]

84. Voegtlin, C.; Frisch, C.; Walther, A.; Schwab, P. Theoretical development and empirical examination of a three-roles model of responsible leadership. SSRN Electron. J. 2019, 167, 411-431. [CrossRef]

85. The Globally Responsible Leader: A Call for Action. Available online: http://grli.org/wp-content/uploads/2017/12/GRLI-Callfor-Action-English-2009-ISBN-978--1-871992--53--3.pdf (accessed on 15 July 2019).

86. Doh, J.P.; Stumpf, S.A.; Tymon, W.G. Responsible leadership helps retain talent in India. J. Bus. Ethics 2011, 98, 85-100. [CrossRef]

87. Lips-Wiersma, M.; Haar, J.; Wright, S. The effect of fairness, responsible leadership, and worthy work on multiple dimensions of meaningful work. J. Bus. Ethics 2020, 161, 35-52. [CrossRef]

88. Mousa, M. Responsible leadership and organizational commitment among physicians: Can inclusive diversity climate enhance the relationship? J. Intercult. Manag. 2017, 9, 103-141. [CrossRef]

89. Voegtlin, C. Development of a scale measuring discursive responsible leadership. J. Bus. Ethics 2011, 98, 57-73. [CrossRef]

90. Mousa, M. Inspiring work-life balance: Responsible leadership among female pharmacists in the Egypt health sector. Entrep. Bus. Econ. Rev. 2018, 6, 71-90. [CrossRef]

91. Javed, M.; Rashid, M.A.; Hussain, G.; Ali, H.Y. The effects of corporate social responsibility on corporate reputation and firm financial performance: Moderating role of responsible leadership. Corp. Soc. Responsib. Environ. Manag. 2019, 27, 1395-1409. [CrossRef]

92. Liao, Z.; Zhang, M. The influence of responsible leadership on environmental innovation and environmental performance: The moderating role of managerial discretion. Corp. Soc. Responsib. Environ. Manag. 2020, 27, 2016-2027. [CrossRef]

93. Iqbal, Q.; Ahmad, N. Sustainable development: The colors of sustainable leadership in learning organization. Sustain. Dev. 2020, 29, 108-119. [CrossRef]

94. Afsar, B.; Maqsoom, A.; Shahjehan, A.; Afridi, S.A.; Nawaz, A.; Fazliani, H. Responsible leadership and employee's proenvironmental behavior: The role of organizational commitment, green shared vision, and internal environmental locus of control. Corp. Soc. Responsib. Environ. Manag. 2019, 27, 297-312. [CrossRef]

95. Cheng, K.; Wei, F.; Lin, Y. The trickle-down effect of responsible leadership on unethical pro-organizational behavior: The moderating role of leader-follower value congruence. J. Bus. Res. 2019, 102, 34-43. [CrossRef]

96. Haque, A.; Fernando, M.; Caputi, P. The relationship between responsible leadership and organizational commitment and the mediating effect of employee turnover intentions: An empirical study with Australian employees. J. Bus. Ethics 2019, 156, 759-774. [CrossRef]

97. He, J.; Morrison, A.; Zhang, H. Being sustainable: The three-way interactive effects of CSR, green human resource management, and responsible leadership on employee green behavior and task performance. Corp. Soc. Responsib. Environ. Manag. 2020, $28,1-12$.

98. Mousa, M.; Puhakka, V. Inspiring organizational commitment. J. Manag. Dev. 2019, 38, 208-224. [CrossRef]

99. Aburdene, P. Megatrends 2010: The Rise of Conscious Capitalism; Hampton Roads Publishing: Charlottesville, VA, USA, 2005.

100. Strong, M. Be the Solution: How Entrepreneurs and Conscious Capitalists can Solve All the World's Problems; John Wiley \& Sons: Hoboken, NJ, USA, 2009.

101. Fyke, J.; Bushnell, P. The ethics of conscious capitalism: Wicked problems in leading change and changing leaders. Hum. Relat. 2013, 66, 1619-1643. [CrossRef]

102. Legault, M. Conscious capitalism: Leaders and organizations with a world view. Integral Leadersh. Rev. 2012, 12, 1-9. Available online: http:/ /integralleadershipreview.com/6686-conscious-capitalism-leaders-and-organizations-with-a-world-view / (accessed on 13 March 2020).

103. Sisodia, R. Conscious capitalism: A better way to win. Calif. Manag. Rev. 2011, 53, 98-108. [CrossRef]

104. Conscious Capitalist Credo. Available online: https:/ / www.consciouscapitalism.org/credo (accessed on 11 May 2019 ).

105. Sisodia, R.; Wolfe, D.B.; Seth, J. Firms of Endearment: How World-Class Companies Profit from Passion and Purpose; Wharton School Publishing: Upper Saddle River, NJ, USA, 2007. 
106. Simpson, S.; Fischer, B.; Rohde, M. The conscious capitalism philosophy pay off: A qualitative and financial analysis of conscious capitalism corporations. J. Leadersh. Account. Ethics 2013, 10, 19-29.

107. Pillay, S.; Sisodia, R. A case for conscious capitalism: Conscious leadership through the lens of brain science. Ivey Bus. J. 2011, 75, 1-4. Available online: https:/ /iveybusinessjournal.com/publication/a-case-for-conscious-capitalism-conscious-leadershipthrough-the-lens-of-brain-science/ (accessed on 5 March 2020).

108. Fry, L.W. Toward a Theory of spiritual leadership. Leadersh. Q. 2003, 14, 693-727. [CrossRef]

109. Benefiel, M.; Fry, L.W.; Geigle, D. Spirituality and religion in the workplace: History, theory, and research. Psychol. Relig. Spiritual. 2014, 6, 175-187. [CrossRef]

110. Oh, J.; Wang, J. Spiritual leadership: Current status and agenda for future research and practice. J. Manag. Spiritual. Relig. 2020, 17, 223-248. [CrossRef]

111. Samul, J. Spiritual Leadership: Meaning in the sustainable workplace. Sustainability 2020, 12, 267. [CrossRef]

112. Mendenhall, M.E.; Reiche, B.S.; Bird, A.; Osland, J.S. Defining the "global" in global leadership. J. World Bus. 2015, 47, 493-503. [CrossRef]

113. Bird, A.; Mendenhall, M.; Stevens, M.J.; Oddou, G. Defining the content domain of intercultural competence for global leaders. J. Manag. Psychol. 2010, 25, 810-828. [CrossRef]

114. Osland, J.S. Leading global change. In Global Leadership: Research, Practice, and Development; Mendenhall, M.E., Osland, J., Bird, A., Oddou, G.R., Stevens, M.S., Maznevski, M., Stahl, G.K., Eds.; Routledge: New York, NY, USA, 2018; pp. 131-159.

115. Beechler, S.; Javidan, M. Leading with a global mindset. In Advances in International Management: The Global Mindset; Javidan, M., Steers, R.M., Hitt, M.A., Eds.; Elsevier: Oxford, UK, 2007; pp. 131-169.

116. Crews, D.E. Strategies for implementing sustainability. Sam Adv. Manag. J. 2010, 75, 15-21. Available online: https://www. academia.edu/7049157/Strategies_for_Implementing_Sustainability_Five_Leadership_Challenges (accessed on 3 March 2019).

117. Elkington, J. Partnerships from cannibals with forks: The triple bottom line of 21st-century business. Environ. Qual. Manag. 1998, 8, 37-51. [CrossRef]

118. Sveningsson, S.; Alvesson, M. Global leadership: Sustaining classic managerialism. In Research Handbook of Global Leadership; Zander, L., Ed.; Edward Elgar Publishing: Cheltenham, UK, 2020; pp. 39-53.

119. Bird, A.; Osland, J.S.; Lane, H.W. Global competencies: An introduction. Blackwell Handb. Glob. Manag. A Guide Manag. Complex. 2004, 57-80. [CrossRef]

120. McCall, M.W.; Hollenbeck, G.P. Developing Global Executives: The Lessons of International Experience; Harvard Business Press: Boston, MA, USA, 2002.

121. Story, J.S.; Barbuto, J.E., Jr.; Luthans, F.; Bovaird, J.A. Meeting the challenges of effective international HRM: Analysis of the antecedents of global mindset. Hum. Resour. Manag. 2014, 53, 131-155. [CrossRef]

122. Levy, O.; Taylor, S.; Boyacigiller, N.A.; Beechler, S. Global mindset: A review and proposed extensions. Adv. Int. Manag. Glob. Mindset 2007. [CrossRef]

123. Cavanagh, G.F.; Moberg, D.J.; Velasquez, M. Making business ethics practical. Bus. Ethics Q. 1995, 5, 399-418. [CrossRef]

124. Johnson, L.E. A Morally Deep World: An Essay on Moral Significance and Environmental Ethics; Cambridge University Press: Cambridge, UK, 1993.

125. Opotow, S. Moral exclusion and injustice: An introduction. J. Soc. Issues 1990, 46, 1-20. [CrossRef]

126. Callicot, J.B. Traditional American Indian and Western European attitudes toward nature. In Postmodern Environmental Ethics; Oelschlaeger, M., Ed.; SUNY Press: Albany, NY, USA, 1995; pp. 192-220.

127. Ulrich, P. Integrative Economic Ethics; Cambridge University Press: New York, NY, USA, 2008.

128. Jonas, H. The Imperative of Responsibility: In Search of an Ethics for the Technological Age; Chicago University Press: Chicago, IL, USA, 1984.

129. Zolnai, L. Competitiveness and Corporate Social Responsibility, Corvinus University of Budapest, CSR PAPER 2.2006. Available online: http:/ /195.130.87.21:8080/dspace/bitstream/123456789/1200/1/Competitiveness\%20and\%20corporate\%20social\%20 responsibility.pdf (accessed on 29 September 2019).

130. Reiter, S.A. The Kohlberg-Gilligan controversy: Lessons for accounting ethics education. Crit. Perspect. Account. 1996, 7, 33-54. [CrossRef]

131. Ciulla, J.B. Leadership and the ethics of care. J. Bus. Ethics 2009, 88, 3-4. [CrossRef]

132. Gilligan, C. In a different voice: Women's conceptions of self and of morality. Harv. Educ. Rev. 1977, 47, 481-517. [CrossRef]

133. Heidegger, M. Being and Time, Translated by Joan Stambaugh; State University of New York Press: Albany, NY, USA, 1996.

134. Carlton, A.; Murphy, C.; Clark, J. A (Blurry) vision of the future: How leader rhetoric about ultimate goals influences performance. Acad. Manag. J. 2014, 57, 1544-1570. [CrossRef]

135. Daft, R.L.; Lengel, R.H. Fusion Leadership: Unlocking the Subtle Forces that Change People and Organizations; Berrett-Koehler Publishers: San Francisco, CA, USA, 1998.

136. MacArthur, J.F. the Footsteps of Faith; Crossway Books: Wheaton, IL, USA, 1998.

137. Sweeney, P.; Hannah, S.; Snider, D. The domain of the human spirit. In Forging the Warrior's Character: Moral Precepts from the Cadet Prayer; Snider, D.M., Matthews, L.J., Eds.; Jerico: Sisters, OR, USA, 2007; pp. 55-99.

138. Turak, A. Brother John: A Monk, a Pilgrim and the Purpose of Life; Clovercroft Publishing: Franklin, TN, USA, 2018.

139. Fleischman, P.R. The Healing Spirit: Explorations in Religion E Psychotherapy; Bonne Chance Press: Cleveland, OH, USA, 1994. 
140. Gasca, P. In This Single Statement, CEOs from the Largest U.S. Corporations Just Changed the Purpose of Business. Inc. Available online: https://www.inc.com/peter-gasca/in-this-single-statement-ceos-from-largest-us-corporations-just-changedpurpose-of-business.html (accessed on 12 April 2019).

141. Hristov, I.; Chirico, A. The role of sustainability key performance indicators (KPIs) in implementing sustainable strategies. Sustainability 2019, 11, 5742. [CrossRef]

142. Hourneaux, F., Jr.; Gabriel, M.; Gallardo-Vazquez, D. Triple bottom line and sustainable performance measurement in industrial companies. TBL Sustain. Perform. Meas. 2018, 25, 413-429. [CrossRef]

143. Metcalf, L.; Benn, S. Leadership for sustainability: An evolution of leadership ability. J. Bus. Ethics 2013, 112, 369-384. [CrossRef]

144. Bartunek, J.M. Changing interpretive schemes and organizational restructuring: The example of a religious order. Adm. Sci. $Q$. 1984, 29, 355-372. [CrossRef]

145. French, W.; Weiss, A. An ethics of care or an ethics of justice. J. Bus. Ethics 2000, 27, 125-136. Available online: http://www.jstor. org/stable/25074369 (accessed on 22 March 2019). [CrossRef]

146. D'Souza, C.; Taghian, M.; Sullivan-Mort, G.; Gilmore, A. An evaluation of the role of green marketing and a firm's internal practices for environmental sustainability. J. Strateg. Mark. 2015, 23, 600-615. [CrossRef]

147. Berry, L.L. Discovering the Soul of Service: The Nine Drivers of Sustainable Business Success; Simon and Schuster: New York, NY, USA, 1999.

148. Fry, L. Toward a Theory of ethical and spiritual well-being, and corporate social responsibility through spiritual leadership. In Positive Psychology in Business Ethics and Corporate Responsibility Information; Giacalone, R.A., Jurkiewicz, C.L., Dunn, C., Eds.; Age Publishing: Greenwich, CT, USA, 2005; pp. 47-83.

149. Fry, L.; Matherly, L.; Ouimet, R. The spiritual leadership balanced scorecard business model: The case of the Cordon-Bleu-Tomasso Corporation. J. Manag. Spiritual. Relig. 2010, 7, 283-315. [CrossRef]

150. Fry, L.; Altman, Y. Spiritual Leadership in Action: The CEL Story; Information Age Publishing: Charlotte, NC, USA, 2013.

151. Fry, L.; Egle, E. Spiritual leadership: Embedding sustainability in the triple bottom line. Graziadio Bus. Rev. 2017, 20. Available online: https: / /gbr.pepperdine.edu/2017/12/spiritual-leadership/ (accessed on 11 January 2020).

152. Buckley, T.; Campbell, M. If Unilever Can't Make Feel-Good Capitalism Work, Who Can? Bus. Week 2017, 46-51. Available online: https: / / www.bloomberg.com/news/features/2017-08-31/if-unilever-can-t-make-feel-good-capitalism-work-who-can (accessed on 2 June 2021).

153. Kabat-Zinn, J. Mindfulness for Beginners: Reclaiming the Present Moment-and Your Life; Sounds True: Louisville, CO, USA, 2012.

154. Kornfield, J. Meditation for Beginners; Jaico Publishing House: Mumbai, India, 2010.

155. Tolle, E. Practicing the Power of Now; New World Library: Novato, CA, USA, 1999.

156. Allen, S.; Fry, L. Spiritual development in executive coaching. J. Manag. Dev. 2019, 38, 796-811. [CrossRef]

157. Reb, J.; Atkins, P.W. Mindfulness in Organizations: Foundations, Research, and Applications; Cambridge University Press: Cambridge, $\mathrm{UK}, 2017$.

158. Fry, L.; Egel, E. Global Leader and Leadership for Sustainability. In Proceedings of the Academy of Management, Boston, MA, USA, 10 August 2019.

159. Pearce, C.; Stahl, G. Introduction to the special issue. The leadership imperative for sustainability and corporate social responsibility. Organ. Dyn. 2015, 44, 83-86. [CrossRef] 